Thermodynamic analyses of municipal solid waste gasification plant integrated with solid oxide fuel cell and Stirling hybrid system

\title{
Rokni, Masoud
}

Published in:

International Journal of Hydrogen Energy

Link to article, DOI:

10.1016/j.ijhydene.2014.11.046

Publication date:

2015

Document Version

Peer reviewed version

Link back to DTU Orbit

\section{Citation (APA):}

Rokni, M. (2015). Thermodynamic analyses of municipal solid waste gasification plant integrated with solid oxide fuel cell and Stirling hybrid system. International Journal of Hydrogen Energy, 40(24), 7855-7869.

https://doi.org/10.1016/j.ijhydene.2014.11.046

\section{General rights}

Copyright and moral rights for the publications made accessible in the public portal are retained by the authors and/or other copyright owners and it is a condition of accessing publications that users recognise and abide by the legal requirements associated with these rights.

- Users may download and print one copy of any publication from the public portal for the purpose of private study or research.

- You may not further distribute the material or use it for any profit-making activity or commercial gain

- You may freely distribute the URL identifying the publication in the public portal 


\title{
Thermodynamic Analyses of a Municipal Solid Waste Gasification Plant Integrated with Solid Oxide Fuel Cell and Stirling Hybrid Systems
}

\author{
Masoud Rokni \\ Technical University of Denmark, Department of Mechanical Engineering, Thermal Energy \\ Section \\ Building 403, 2800 Kgs, Lyngby, Denmark. \\ E-mail:MR@mek.dtu.dk
}

\begin{abstract}
Municipal Solid Waste (MSW) can be considered a valid biomass to be used in a power plant. The major advantage is the reduction of pollutants and greenhouse gases emissions not only within large cities but also globally. Another advantage is that by their use it is possible to reduce the waste storage in landfills and devote these spaces to other human activities. It is also important to point out that this kind of renewable energy suffers significantly less availability which characterizes other type of renewable energy sources such as in wind and solar energy.

In a gasification process, waste is subject to chemical treatments through air or/and steam utilization; the result is a synthesis gas, called "Syngas" which is principally composed of hydrogen and carbon monoxide. Traces of hydrogen sulfide could also be present which can easily be separated in a desulfurization reactor. The gasification process is usually based on an atmospheric-pressure circulating fluidized bed gasifier coupled to a tar-cracking vessel. Syngas can be used as fuel in different kind of power plant such as gas turbine cycle, steam cycle, combined cycle, internal and external combustion engine and Solid Oxide Fuel Cell (SOFC).

In the present study, a MSW gasification plant integrated with SOFC is combined with a Stirling engine to recover the energy of the off-gases from the topping SOFC cycle. Detailed plant design is proposed and thermodynamic analysis is performed. Relevant parameters have been studied to optimize the plant efficiency in terms of operating conditions. Compared with modern waste incinerators with heat recovery, the gasification process integrated with SOFC and Stirling engine permits an increase in electricity output up of $50 \%$, which means that the solid waste gasification process can compete with incineration technologies. Moreover waste incinerators require the installation of sophisticated exhaust gas cleaning equipment that can be large and expensive and are not necessary in the studied plant.
\end{abstract}

Keywords: Solid oxide fuel cell (SOFC), Fuel cell, Hybrid cycle, Stirling engine, Gasification, Municipal solid waste

\section{Introduction}

Owing to the ever-increasing demand for more efficient power production and distribution, improving production and distribution efficiencies and reducing pollutant emissions continue to be the main areas of research and development in the field of electricity production. Currently, there is an increased interest in developing distributed systems consisting of small-scale facilities at a single location, allowing electricity and heat to be produced and distributed close to the end user, thereby minimizing the costs associated with transportation $[1,2]$. 
The term "biomass" refers to vegetable and animal substances that do not have a fossil origin and can be used as fuel in a power plant for the production of electrical energy. Biomass derived from living or recently living biological organisms can be considered to be a particular kind of renewable energy source, because the carbon dioxide released into the atmosphere by their use is compensated for by the amount of carbon absorbed during their life. In the case of such biomass, the most important pollutants linked to biomass utilization are related to transport, manufacture, and transformation processes. Municipal solid waste (MSW) is one such type of biomass and is suitable for use in power plants. It presents some advantages such as the reduction of pollutants and greenhouse gas emissions and the possibility of reducing storage in landfills, as a result of which these spaces can be devoted to other human activities.

It is also important to point out that this kind of renewable energy has a significantly low availability, which also characterizes the other types of renewable energy sources such as wind and solar energy. As suggested by Morris and Waldheim [3], a well-designed waste management system should prevent waste generation, recycle waste materials, reduce landfill disposal to a minimum, incinerate with energy recovery at efficiencies comparable to alternative technologies, must utilize sophisticated exhaust gas cleaning equipment, and must incorporate gasification processes.

In a gasification process, the waste is subjected to chemical treatments through air or steam utilization. Synthesis gas, also known as "syngas", which is principally composed of $\mathrm{H}_{2}$ and $\mathrm{CO}$, is produced as a result of the gasification process. Traces of $\mathrm{H}_{2} \mathrm{~S}$ and other contaminants may also be present and can be separated in a desulfurization reactor and/or a fuel conditioning system. The gasification process is usually performed in a fluidized bed gasifier under atmospheric pressure, coupled with a tar-cracking vessel. The produced gas is then cleaned and the syngas can be used as a fuel in various kinds of power plants such as gas turbine cycles, steam cycles, combined cycles, internal and external combustion engines, and SOFCs.

SOFCs are one of the most promising type of fuel cells, particularly in terms of energy production. They are expected to produce clean electrical energy at high conversion rates with low noise and low pollutant emissions [4]. SOFC stacks may soon enter the commercialization phase. In addition, small Stirling engines are also approaching the commercialization phase. Therefore, it would be interesting to integrate these two technologies into a single system that would combine the benefits of each system, thereby establishing a new technology. By integrating this combined system with a gasification plant that gasifies MSWs, electricity and heat energy could then be produced in an environmentally friendly manner.

To date, studies on the use of syngas generated from coal and biomass gasification as a feed for SOFCs have been carried out $[5,6]$. The use of synthetic wood gas for operating SOFCs has also been experimentally studied [7] and it has been shown that wood gas obtained from air gasification always provides a stable performance, whereas the performance results for the wood gas obtained from steam gasification are inconclusive.

The exhaust temperatures of SOFCs are high owing to the high operating temperature of the cells. Additionally, since the fuel utilization in the fuel cell is less than 100 percent, the unreacted fuel needs to be combusted in a burner. The combustion process, in turn produces even hotter off-gases that are perfectly suited for use in heat engines such as a Stirling engine, for the production of power and heat for domestic purposes.

Numerous studies in the literature have investigated SOFC-based power systems and have reported high thermal efficiencies. However, the majority of these studies use gas turbines as the bottoming cycle $[8,9,10]$. In addition, steam turbines have also been used as bottoming cycles $[11,12]$, resulting in high plant efficiencies without pressurizing the fuel cells. Only a few studies have been carried out with a Stirling engine as the bottoming cycle and a fuel cell cycle as the topping cycle $[1,2]$. At present, using the Brayton and Rankine cycles as bottoming cycles 
appears to be the most practical method, owing to the maturity of these technologies. The development trends in the field of SOFCs suggest that the operating temperature of the SOFCs will decrease in the future. As a result, using a gas turbine as the bottoming cycle will become less beneficial over time.

Introducing a heat engine (such as a Stirling engine) as the bottoming cycle for SOFCs instead of gas turbines and steam cycles has several advantages. Such a hybrid cycle is significantly less complex and heat production can match the high electrical powers obtained (high heat-power ratio). In addition, small-scale combined heat and power (CHP) plants suitable for hotels, hospitals, and shopping centers can be built at much lower plant costs.

Integrated gasification SOFC systems have also been previously studied [13, 14, 15]. Coal gasification with a complex syngas fuel conditioning system has also been integrated with SOFCs and studied widely in the literature $[16,17]$. However, there has been a void in research in the area of integrated MSW gasification-SOFC-Stirling CHP plants in the literature, which form the basis for this study.

The present work is a thermodynamic investigation of integrated systems consisting of an MSW gasification plant, SOFCs, and a Stirling engine. The syngas produced from the gasification unit is used as the fuel for the SOFC plant that also functions as a topping cycle for a Stirling engine, which uses the heat from the off-gases released from the topping cycle. The net capacity of the system is $120 \mathrm{~kW}$, which is suitable for use in decentralized CPH plants. The gasifier type used in this study is adopted from the two-stage autothermal (air-blown) fixed-bed gasifier built at DTU (Technical University of Denmark)-Ris $\emptyset$. More information on the gasifier plant can be found in previous publications $[18,19,20]$. The SOFC is based on a theoretical model with empirical coefficients determined from experimental data. The Stirling engine's parameters are chosen by fitting these parameters to a validated feasible engine.

No investigations on MSW gasification plants integrated with SOFCs and a Stirling engine are available in the open literature. Therefore, the current investigation is completely novel and is expected to help in generating new ideas for designing new energy system configurations for future applications. It should also be noted that the system presented here is studied thermodynamically and that the objective of this study is not to present or discuss the associated costs. The performances of the various plants are compared in terms of efficiency, fuel consumption, and other related parameters. In summary, the primary goal of this study is to use MSW to generate electricity and heat through gasification, SOFCs, and a Stirling engine.

\section{Plant Design and Modeling}

The principal components of the plant are the gasification unit, the SOFC unit, and the Stirling engine. The gasification plant converts the MSW into syngas, which is a mixture of $\mathrm{H}_{2}$, $\mathrm{N}_{2}, \mathrm{CO}, \mathrm{CO}_{2}, \mathrm{H}_{2} \mathrm{O}, \mathrm{CH}_{4}$, and Ar. The syngas produced is subsequently cleaned to remove traces of undesired particle contaminants that could potentially poison the SOFC. The clean syngas is sent to the SOFC plant to produce electricity. The SOFC stacks are unable to consume all the fuel and the unconsumed fuel is sent to the burner to complete the combustion. The combusted gases after processing through the burner are sent to a Stirling engine (which acts as the bottoming cycle) for further electricity production. Both the engine cooling circuit and the heat released through the released gases can be used for space heating and domestic hot water (DHW) production (Fig. 1).

Apart from the fuel, the other inputs to the plant are the air feeding the gasifier and the cathode side of the SOFC stacks. In order to introduce these air feeds, auxiliary energy such as 
compressors is necessary. In addition, auxiliary energy is also required to blow the syngas out of the gasification plant.

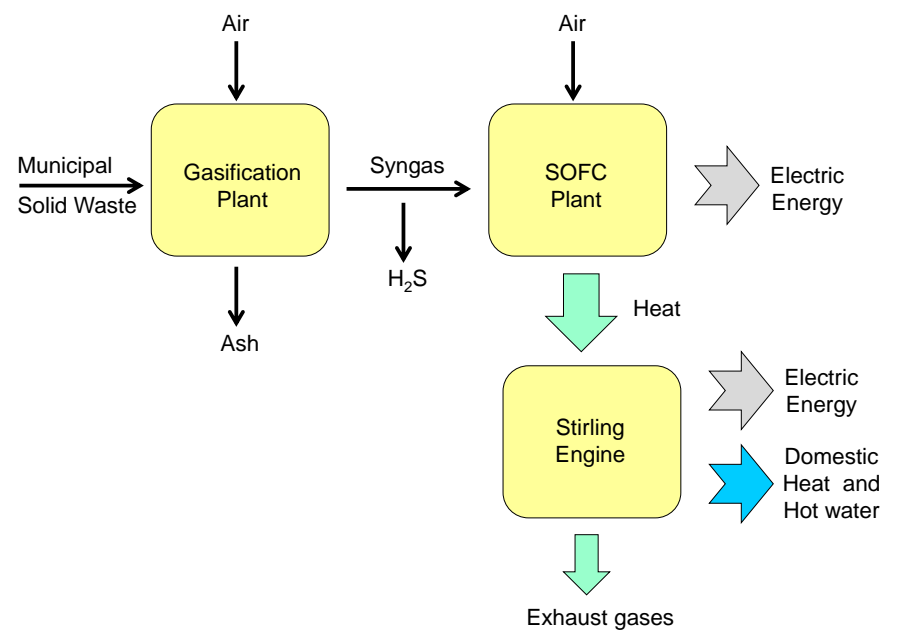

Figure 1. Block scheme of the plant.

The efficiency of the plant can be expressed as a ratio of the net electric power to the fuel power (equation 1), where the net electric power refers to the difference between the total produced power and the power used in the auxiliary components such as compressors, blowers, control systems, etc.

$$
\eta=\frac{P_{\text {Net }}}{\dot{m}_{\text {fuel }} L H V_{\text {fuel }}}=\frac{P_{\text {Tot }}-P_{\text {Aux }}}{\dot{m}_{\text {fuel }} L H V_{\text {fuel }}}
$$

\subsection{Modeling of the Gasifier}

The gasification plant used in this study is based on the model developed in a previous report [15]. The model is briefly described here for clarity. A simple Gibbs reactor, where the total Gibbs free energy is minimized upon reaching chemical equilibrium, is implemented to calculate the gas composition at a specified temperature and pressure without considering the reaction pathways [21]. The Gibbs free energy of a gas (which is assumed to be a mixture of $k$ perfect gases) is given by equation 2 .

$$
\dot{G}=\sum_{i=1}^{k} \dot{n}_{i}\left[g_{i}^{0}+R T \ln \left(n_{i} p\right)\right]
$$

where $g^{0}, R$, and $T$ are the specific Gibbs free energy, universal gas constant, and gas temperature respectively. Each element in the inlet gas is in balance with the outlet gas composition, implying that the flow of each constituent has to be conserved. For $N$ elements, this balance is expressed by equation 3 [15].

$$
\sum_{i=1}^{k} \dot{n}_{i, i n} \mathbf{A}_{i j}=\sum_{m=1}^{w} \dot{n}_{m, o u t} \mathbf{A}_{m j} \quad \text { for } j=1, N
$$

The $N$ elements correspond to $\mathrm{H}_{2}, \mathrm{O}_{2}, \mathrm{~N}_{2}, \mathrm{CO}, \mathrm{NO}, \mathrm{CO}_{2}$, steam, $\mathrm{NH}_{3}, \mathrm{H}_{2} \mathrm{~S}, \mathrm{SO}_{2}, \mathrm{CH}_{4}, \mathrm{C}, \mathrm{NO}_{2}$, $\mathrm{HCN}$ (hydrogen cyanide), $\mathrm{COS}$ (carbonyl sulfide), $\mathrm{Ar}$, and ashes $\left(\mathrm{SiO}_{2}\right)$ in the gasification process. $A_{m j}$ is the number of atoms of element $\mathrm{j}(\mathrm{H}, \mathrm{C}, \mathrm{O}$, and $\mathrm{N})$ in each molecule of the entering compound $\mathrm{i}\left(\mathrm{H}_{2}, \mathrm{CH}_{4}, \mathrm{CO}, \mathrm{CO}_{2}, \mathrm{H}_{2} \mathrm{O}, \mathrm{O}_{2}, \mathrm{~N}_{2}\right.$, and $\left.\mathrm{Ar}\right)$, whereas $\mathrm{A}_{\mathrm{ij}}$ is the number of 
atoms of element $j$ in each molecule of the leaving compound $m\left(\mathrm{H}_{2}, \mathrm{O}_{2}, \mathrm{~N}_{2}, \mathrm{CO}, \mathrm{NO}, \mathrm{CO}_{2}\right.$, steam, $\mathrm{NH}_{3}, \mathrm{H}_{2} \mathrm{~S}, \mathrm{SO}_{2}, \mathrm{CH}_{4}, \mathrm{C}, \mathrm{NO}_{2}, \mathrm{HCN}, \mathrm{COS}$, Ar, and ashes). The minimization of the Gibbs free energy can be mathematically formulated by introducing a Lagrange multiplier $(\mu)$ for each of the $N$ constraints. After adding the constraints, the expression to be minimized is given by equation 4.

$$
\phi=\dot{G}_{\text {tot }, \text { out }}+\sum_{j=1}^{N} \mu_{j}\left(\sum_{i=1}^{k} \dot{n}_{i, \text { out }} A_{i j}-\sum_{m=1}^{w} \dot{n}_{m, i n} A_{m j}\right)
$$

By setting the partial derivative of this equation with respect to $\dot{n}_{i, \text { out }}$ to zero, the function $\phi$ can be minimized as

$$
\begin{aligned}
& \frac{\partial \phi}{\partial \dot{n}_{i, \text { out }}}=\frac{\partial \dot{G}_{\text {tot }, \text { out }}}{\partial \dot{n}_{i, \text { out }}}+\sum_{j=1}^{N} \mu_{j} \mathbf{A}_{i j}=0 \quad \text { for } i=1, k \\
& \Rightarrow \quad g_{i, \text { out }}^{0}+R T \ln \left(n_{i, \text { out }} p_{\text {out }}\right)+\sum_{j=1}^{N} \mu_{j} \mathbf{A}_{i j}=0 \quad \text { for } i=1, k
\end{aligned}
$$

Thus, a set of $k$ equations are defined for each chemical compound leaving the system.

Finally, it is realizable that by assuming chemical equilibrium in the gasifier, the methane content in the product gas can be underestimated. Therefore, a parameter called METHANE is applied to allow some of the methane to bypass the gasifier without undergoing any chemical reactions. The value of this parameter is assumed to be 0.01 , meaning that $1 \%$ of the methane bypassed the gasifier. It may be noted that other values can be selected. Owing to the lack of experimental data, further investigations on the choice of this value were not conducted.

The basic MSW composition and the properties used in this study are shown in Table 1, which are based on a previously published study [22]. This MSW composition should be assumed, unless other values are specified. It may be noted that the compositions are expressed on a dry basis (i.e., weight fraction without moisture content). The MSW composition is then changed as discussed below.

Table 1. Municipal solid waste compositions and properties used in this study.

\begin{tabular}{c|c}
\hline MSW & $\begin{array}{c}\text { Dry-based } \\
\text { percentage }\end{array}$ \\
\hline C [\%] & 47.6 \\
H [\%] & 6 \\
O [\%] & 32.9 \\
S [\%] & 0.3 \\
N [\%] & 1.2 \\
Ash [\%] & 12 \\
LHV [kW], (dry basis) & 19879 \\
c $_{\mathrm{p}}[\mathrm{kJ} / \mathrm{kg}]$ & 1.71 \\
Moisture & 0.095 \\
\hline
\end{tabular}

\subsection{Modeling of SOFCs}

The SOFC model proposed in a previous study [15] is adopted in this investigation and has been validated with experimental data on planar SOFCs. In the development of such models, 
one must distinguish between electrochemical modeling, the calculation of cell irreversibility (cell voltage efficiency), and the species compositions at the outlet. For electrochemical modeling, the operational voltage $\left(E_{\text {cell }}\right)$ was represented by equation 6 .

$$
E_{\text {cell }}=E_{\text {Nernst }}-\Delta E_{\text {act }}-\Delta E_{\text {ohm }}-\Delta E_{\text {conc }}
$$

where $E_{\text {Nernst }}, \Delta E_{a c t}, \Delta E_{o h m}$, and $\Delta E_{\text {conc }}$ are the Nernst ideal reversible voltage, activation polarization, ohmic polarization, and concentration polarization, respectively. Assuming that only $\mathrm{H}_{2}$ is electrochemically converted, the Nernst equation can be written as shown in equations 7 and 8.

$$
\begin{aligned}
& E_{\text {Nernst }}=\frac{-\Delta g_{\mathrm{f}}{ }^{0}}{n_{\mathrm{e}} F}+\frac{R T}{n_{\mathrm{e}} F} \ln \left(\frac{p_{\mathrm{H}_{2}, \text { tot }} \sqrt{p_{\mathrm{O}_{2}}}}{p_{\mathrm{H}_{2} \mathrm{O}}}\right) \\
& p_{\mathrm{H} 2, \mathrm{tot}}=p_{\mathrm{H} 2}+p_{\mathrm{CO}}+4 p_{\mathrm{CH} 4}
\end{aligned}
$$

where $\Delta g_{f}^{0}$ is the Gibbs free energy (for $\mathrm{H}_{2}$ reaction) at standard temperature and pressure. The water-gas shift reaction is very fast and therefore the assumption that $\mathrm{H}_{2}$ is the only species to be electrochemically converted is justified $[23,24]$. In the above equations, $p_{\mathrm{H} 2}$ and $p_{\mathrm{H} 2 \mathrm{O}}$ are the partial pressures for $\mathrm{H}_{2}$ and $\mathrm{H}_{2} \mathrm{O}$, respectively. It should be noted that the steam reforming and the associated water gas shift reactions are efficiently modeled in the calculations.

The activation polarization can be evaluated using the Butler-Volmer equation [25]. The activation polarization term is isolated from the other polarization terms, to determine the charge transfer coefficients and the exchange current density from the experiments by the curve fitting technique. The activation polarization is expressed by equation 9 .

$$
\Delta E_{a c t}=\frac{R T}{(0.001698 T-1.254) F} \sinh ^{-1}\left[\frac{i_{d}}{2\left(13.087 T-1.096 \times 10^{4}\right)}\right],
$$

where $R, T, F$, and $i_{d}$ are the universal gas constant, operating temperature, Faraday constant, and current density, respectively.

The ohmic polarization [26] depends on the electrical conductivity of the electrodes as well as the ionic conductivity of the electrolyte. This is also validated with experimental data for a cell with a specified anode thickness $\left(t_{a n}\right)$, electrolyte thickness $\left(t_{e l}\right)$, and cathode thickness $\left(t_{c a}\right)$. The ohmic polarization is given as follows.

$$
\Delta E_{o h m}=\left(\frac{t_{a n}}{\sigma_{a n}}+\frac{t_{e l}}{\sigma_{e l}}+\frac{t_{c a}}{\sigma_{c a}}\right) i_{d},
$$

where $t_{a n}=600 \mu \mathrm{m}, t_{e l}=50 \mu \mathrm{m}$, and $t_{c a}=10 \mu \mathrm{m}$. $\sigma_{a n}, \sigma_{e l}$, and $\sigma_{c a}$ are the conductivities of the anode, electrolyte, and cathode, respectively, and may be expressed as follows.

$$
\begin{aligned}
& \sigma_{a n}=10^{5}, \quad \sigma_{c a}=\frac{5.760 \times 10^{7}}{T} \exp \left(-\frac{0.117}{8.617 \times 10^{-5} T}\right) \\
& \sigma_{e l}=8.588 \times 10^{-8} T^{3}-1.101 \times 10^{-4} T^{2}+0.04679 T-6.54
\end{aligned}
$$

The concentration polarization is dominant at high current densities for anode-supported SOFCs, wherein insufficient amounts of reactants are transported to the electrodes and consequently, the voltage is reduced significantly. As in the previous case, the concentration 
polarization was validated with experimental data by introducing the anode limiting current, [27], in which the anode porosity and tortuosity were considered among other parameters. The concentration polarization is modeled as shown in equation 13.

$$
\Delta E_{c o n c}=B\left(\ln \left(1+\frac{p_{H_{2}} i_{d}}{p_{H 2 O} i_{a s}}\right)-\ln \left(1-\frac{i_{d}}{i_{a s}}\right)\right),
$$

where $B$ is the diffusion coefficient, which is determined using a calibration technique as

$$
\mathrm{B}=\left(0.008039 \mathrm{X}_{\mathrm{H} 2}^{-1}-0.007272\right) \frac{T}{T_{\text {ref }}}
$$

$T_{\text {ref }}$ is the reference temperature $(1023 \mathrm{~K})$, and the anode limiting current is defined as

$$
i_{a s}=\frac{2 F p_{H 2} D_{b i n} V_{a n}}{R T t_{a n} \tau_{a n}}
$$

where $V_{a n}$ and $\tau_{a n}$ are the porosity (30\%) and tortuosity $(2.5 \mu \mathrm{m})$ of the anode, respectively. The binary diffusion coefficient is given by

$$
D_{b i n}=\left(-4.107 \times 10^{-5} X_{H 2}+8.704 \times 10^{-5}\right)\left(\frac{T}{T_{r e f}}\right)^{1.75} \frac{p_{r e f}}{p},
$$

which is also calibrated against the experimental data. $p_{\text {ref }}$ is the reference pressure $(1.013$ bar), and $X_{H_{2}}$ is the mass reaction rate of $\mathrm{H}_{2}$. Lastly, the current density $i_{d}$ is directly proportional to the amount of reacting $\mathrm{H}_{2}$ according to Faraday's law (equation 17).

$$
i_{d}=\frac{\dot{n}_{H 2} 2 F}{A}
$$

where $n_{H 2}$ is the molar reaction rate of $\mathrm{H}_{2}$. The area $\mathrm{A}$ is a physical property of the cell and was $144 \mathrm{~cm}^{2}$ in this study.

The SOFC model in this study aims at representing the performance of the second generation SOFC stacks developed by Topsoe Fuel Cell A/S (TOFC) and the Fuel Cells and Solid State Chemistry Division at Ris $\varnothing$ - DTU (Technical University of Denmark). This SOFC type is anode supported, with a Ni/YSZ ${ }^{1}$ anode, a YSZ electrolyte, and an $\mathrm{LSM}^{2} / \mathrm{YSZ}$ cathode [28].

The fuel composition at the anode outlet is calculated using the Gibbs minimization method [21]. Equilibrium at the anode outlet temperature and pressure is assumed for $\mathrm{H}_{2}, \mathrm{CO}, \mathrm{CO}_{2}$, $\mathrm{H}_{2} \mathrm{O}, \mathrm{CH}_{4}$, and $\mathrm{N}_{2}$. Thus, the Gibbs minimization method calculates the compositions of these species at the outlet by minimizing their Gibbs energy. The equilibrium assumption is reasonable, since the methane content in this study is very low.

In order to calculate the voltage efficiency of the SOFC cells, the power production from the SOFCs $\left(P_{S O F C}\right)$, which depends on the amount of chemical energy fed to the anode, the reversible efficiency $\left(\eta_{\text {rev }}\right)$, the voltage efficiency $\left(\eta_{v}\right)$, and the fuel utilization factor $\left(U_{F}\right)$ is evaluated. It is defined in the mathematical form in equation 18.

$$
P_{S O F C}=\left(\mathrm{LHV}_{\mathrm{H}_{2}} \dot{n}_{\mathrm{H}_{2}, \text { in }}+\mathrm{LHV}_{\mathrm{CO}} \dot{n}_{\mathrm{CO}, \text { in }}+\mathrm{LHV}_{\mathrm{CH}_{4}} \dot{n}_{\mathrm{CH}_{4}, \text { in }}\right) \eta_{\text {rev }} \eta_{v} U_{F}
$$

where $U_{F}$ is a constant and $\eta_{v}$ is defined as follows.

\footnotetext{
${ }^{1}$ Yttria-stabilized zirconia.

${ }^{2}$ Lanthanum strontium manganite.
} 


$$
\eta_{\mathrm{v}}=\frac{\Delta E_{\text {cell }}}{E_{\text {Nernst }}}
$$

Note that the utilization factor in SOFCs can be defined as the amount of $\mathrm{O}_{2}$ consumed, because $\mathrm{O}_{2}$ ions are the carriers. The reversible efficiency is the maximum possible efficiency, which is defined as the relationship between the maximum electrical energy available (change in Gibbs free energy) and the LHV (lower heating value) of the fuels, as shown below [29].

$$
\begin{aligned}
& \eta_{\text {rev }}=\frac{\left(\Delta \bar{g}_{f}\right)_{\text {fuel }}}{\mathrm{LHV}_{\text {fuel }}} \\
& \begin{aligned}
\left(\Delta \bar{g}_{f}\right)_{\text {fuel }}= & {\left[\left(\bar{g}_{f}\right)_{\mathrm{H}_{2} \mathrm{O}}-\left(\bar{g}_{f}\right)_{\mathrm{H}_{2}}-\frac{1}{2}\left(\bar{g}_{f}\right)_{\mathrm{O}_{2}}\right] y_{\mathrm{H}_{2}, \text { in }} } \\
+ & {\left[\left[\left(\bar{g}_{f}\right)_{\mathrm{CO}_{2}}-\left(\bar{g}_{f}\right)_{\mathrm{CO}}-\frac{1}{2}\left(\bar{g}_{f}\right)_{\mathrm{O}_{2}}\right] y_{\mathrm{CO}, \text { in }}\right.} \\
+ & +\left[\left(\bar{g}_{f}\right)_{\mathrm{CO}_{2}}+2\left(\bar{g}_{f}\right)_{\mathrm{H}_{2} \mathrm{O}}-\left(\bar{g}_{f}\right)_{\mathrm{CH}_{4}}-2\left(\bar{g}_{f}\right)_{\mathrm{O}_{2}}\right] y_{\mathrm{CH}_{4}, \text { in }}
\end{aligned}
\end{aligned}
$$

where $\Delta \bar{g}$ is the average Gibbs free energy from the inlet to the outlet and $y$ is the mole fraction. The partial pressures are assumed to be the average pressures between the inlet and the outlet.

$$
\begin{aligned}
& \bar{p}_{j}=\left(\frac{y_{j, \text { out }}+y_{j, \text { in }}}{2}\right) \bar{p} \quad j=\left\{\mathrm{H}_{2}, \mathrm{CO}, \mathrm{CH}_{4}, \mathrm{CO}_{2}, \mathrm{H}_{2} \mathrm{O}, \mathrm{N}_{2}\right\} \\
& \bar{p}_{\mathrm{O}_{2}}=\left(\frac{y_{\mathrm{O}_{2}, \text { out }}+y_{\mathrm{O}_{2}, \text { in }}}{2}\right) \bar{p}_{\mathrm{c}}
\end{aligned}
$$

A comparison between the SOFC model developed here and the experimental data is shown in Fig. 2, in terms of current density and cell voltage (IV curve). As seen from the figure, the model captures the experimental data very well at four different cell operating temperatures from $650^{\circ} \mathrm{C}$ to $800^{\circ} \mathrm{C}$, with a standard error of less than 0.01 . Different $\mathrm{H}_{2}$ and water vapor concentrations were used when developing the model. However, only the data for $97 \% \mathrm{H}_{2}$ with $3 \%$ water vapor is shown in Fig. 2.

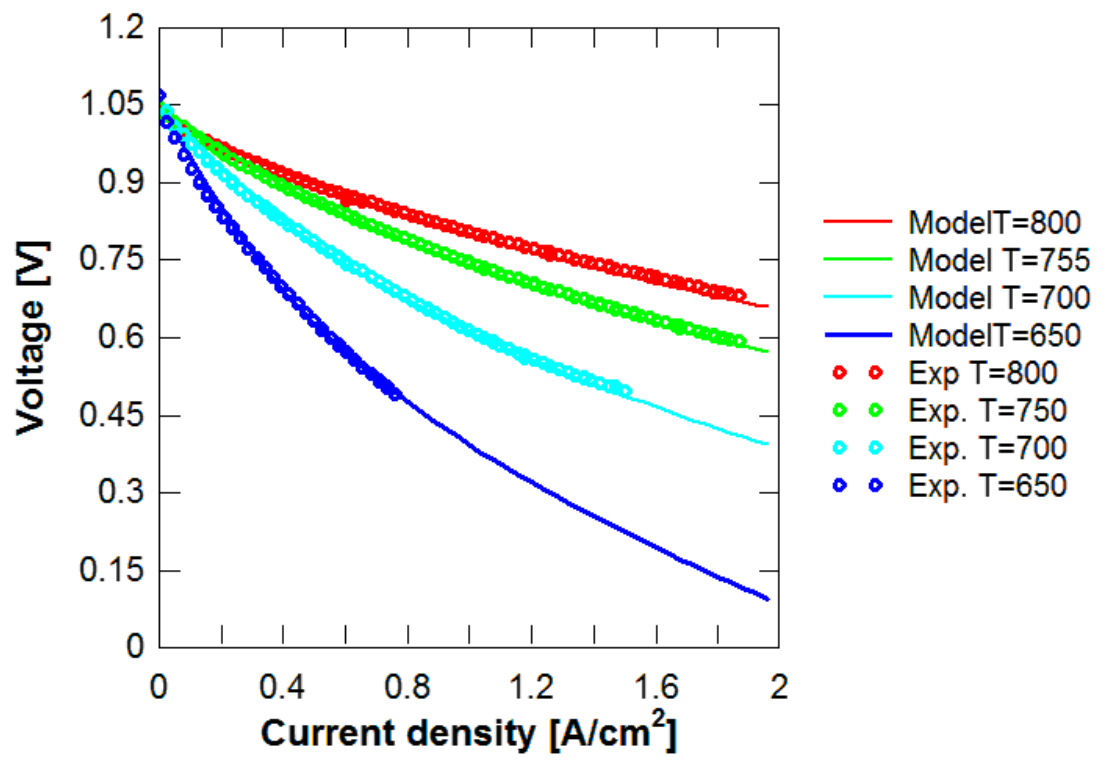


Figure 2. Cell voltage versus current density and a comparison between the modeling results and experimental data with $97 \% \mathrm{H}_{2}$ and $3 \%$ water vapor.

Additionally, equations for conservation of mass (with molar flows), conservation of energy, and conservation of momentum were also included in the model. Table 2 displays the main parameters for the SOFC stacks used in this study.

Table 2. The main SOFC parameters used in this study.

\begin{tabular}{l|c}
\hline \multicolumn{1}{c|}{ Parameter } & Value \\
\hline Fuel utilization factor & 0.675 \\
Number of cells in stack & 74 \\
Number of stacks & 160 \\
Cathode pressure drop ratio (bar) & 0.05 \\
Anode pressure drop ratio (bar) & 0.01 \\
Cathode inlet temperature $\left({ }^{\circ} \mathrm{C}\right)$ & 600 \\
Anode inlet temperature $\left({ }^{\circ} \mathrm{C}\right)$ & 650 \\
Outlet temperatures $\left({ }^{\circ} \mathrm{C}\right)$ & 780 \\
DC/AC convertor efficiency & 0.95 \\
\hline
\end{tabular}

\subsection{Modeling of Stirling Engine}

The Stirling engine model used in this study is adopted from a previously developed model [2], which is a pseudo Stirling cycle, and closely approximates the performance of an actual engine developed by xxx [30]. A brief explanation of how the model is implemented in the inhouse program is provided herein.

The main difference between the pseudo Stirling cycle and the ideal Stirling cycle is the assumption of isentropic compression and expansion in the former versus isothermal compression and expansion in the latter. It is thought that isentropic compression and expansion provide a more realistic view of the cycle performance because by incorporating these processes, the losses encountered in the Stirling engine are accounted for. In the model, the engine is divided into three parts, namely the heater, engine, and a cooler.

The most important parameters of a Stirling engine are the temperature ratio, the compression ratio, the regenerator effectiveness, and the heater effectiveness. Engine power can be determined from engine efficiency and the difference in temperature between the heat source and the heat sink. The heat can be added and removed from the engine using two different heat exchangers for effectiveness. The total loss from the Stirling engine has contributions from various loss mechanisms, including mechanical and thermal processes. Therefore, a "loss factor" is incorporated, which accounts for all the mechanisms of losses in the engine, including mechanical and thermal losses.

The highest temperature of the working fluid (helium) is lower than the heater wall temperature, and the lowest temperature of the working fluid is a weighted temperature, which is an average between the inlet and outlet temperatures. Therefore, the terms $\Delta T_{\text {heater }}$ and $\Delta T_{\text {cooler }}$ referring to the temperature difference over the heater and the cooler, respectively, are introduced. The main parameters for the Stirling engine used in this study are shown in Table 3.

Table 3. The main Stirling engine parameters used in this study.

\begin{tabular}{l|c}
\hline \multicolumn{1}{c|}{ Parameter } & Value \\
\hline Heater and cooler $\Delta \mathrm{p}($ bar $)$ & 0.01 \\
Heater wall temperature $\left({ }^{\circ} \mathrm{C}\right)$ & 600 \\
Heater $\Delta T\left({ }^{\circ} \mathrm{C}\right)$ & 125 \\
\hline
\end{tabular}




\begin{tabular}{l|c}
\hline Heater effectiveness & 0.95 \\
Cooler $\Delta T\left({ }^{\circ} \mathrm{C}\right)$ & 60 \\
Compressor ratio $(-)$ & 1.44 \\
Regenerator effectiveness & 0.98 \\
Mechanical loss factor & 0.8 \\
\hline
\end{tabular}

\subsection{Modeling of Methanator}

A methanator increases the methane content in the fuel by methanation, which is primarily an exothermic reaction of $\mathrm{CO}$ and $\mathrm{H}_{2}$ producing $\mathrm{CH}_{4}$ and steam.

$$
\mathrm{CO}+3 \mathrm{H}_{2} \rightarrow \mathrm{CH}_{4}+\mathrm{H}_{2} \mathrm{O}
$$

However, other minor reactions may also occur depending on the fuel used. To model the methanator, a simple Gibbs reactor is implemented [15, 21], i.e., the total Gibbs free energy is minimized when chemical equilibrium is achieved. For the methanator, $\mathrm{H}_{2}, \mathrm{CO}, \mathrm{CO}_{2}$, steam, $\mathrm{CH}_{4}, \mathrm{~N}_{2}, \mathrm{NO}, \mathrm{H}_{2} \mathrm{~S}, \mathrm{SO}_{2}, \mathrm{NO}_{2}, \mathrm{HCN}, \mathrm{COS}, \mathrm{N}_{2} \mathrm{O}, \mathrm{NO}_{3}, \mathrm{SO}_{3}$, and Ar are considered to be the species at the outlet.

In a catalytic gas burner, the unused fuel is reformed via a highly exothermic process. Furthermore, for all the reforming processes for any component, the Gibbs free energy is minimized to achieve chemical equilibrium.

\subsection{Modeling of Other Components}

Modeling of other components such as heat exchangers, pumps, etc. are adopted from the study of $\mathrm{xxx}$ [2], where the reliability of the components modeling was justified by building a benchmark system consisting of an SOFC, methanator, heat exchanger, etc. and fed with various fuels such as natural gas, ethanol, methanol, and dimethyl ether (DME). The results obtained agreed well with the corresponding data reported by other researchers in the open literature, for all the cases studied.

\subsection{Methodology}

The thermodynamic results in this study were obtained using the Dynamic Network Analysis (DNA) simulation tool [31]. The software is a result of an ongoing project undertaken by the thermal energy section of the Mechanical Department of the Technical University of Denmark, which began with a Master's thesis project [32]. Since then, the program has continuously been developed to adapt it for different energy systems. The program includes a component library, thermodynamic state models for fluids, and standard numerical solvers for differential and algebraic equation systems. The available models in the component library include those for heat exchangers, burners, dryers, turbo machinery, decanters, energy storage systems, valves, and controllers, among others. The thermodynamic state models for fluids cover the most basic fluids and compounds, such as ash and tar, which are used in energy system analyses. The calculation procedure is shown in Fig. 3.

DNA is a component-based simulation tool, meaning that the model is formulated by connecting the components together with nodes and adding operating conditions to create a system. The equations for mass and energy conservation for all the components and nodes are included along with the relations for the thermodynamic properties of the fluids. The total mass balance and energy balance for the entire system is also included, to account for heat loss and heat exchange between different components. In addition, the models for each component include a number of constitutive equations representing their physical properties (e.g., heat transfer coefficients for heat exchangers and isentropic efficiencies for compressors and turbines). The program is written in FORTRAN, and users may also add additional components and thermodynamic state models to the libraries. 


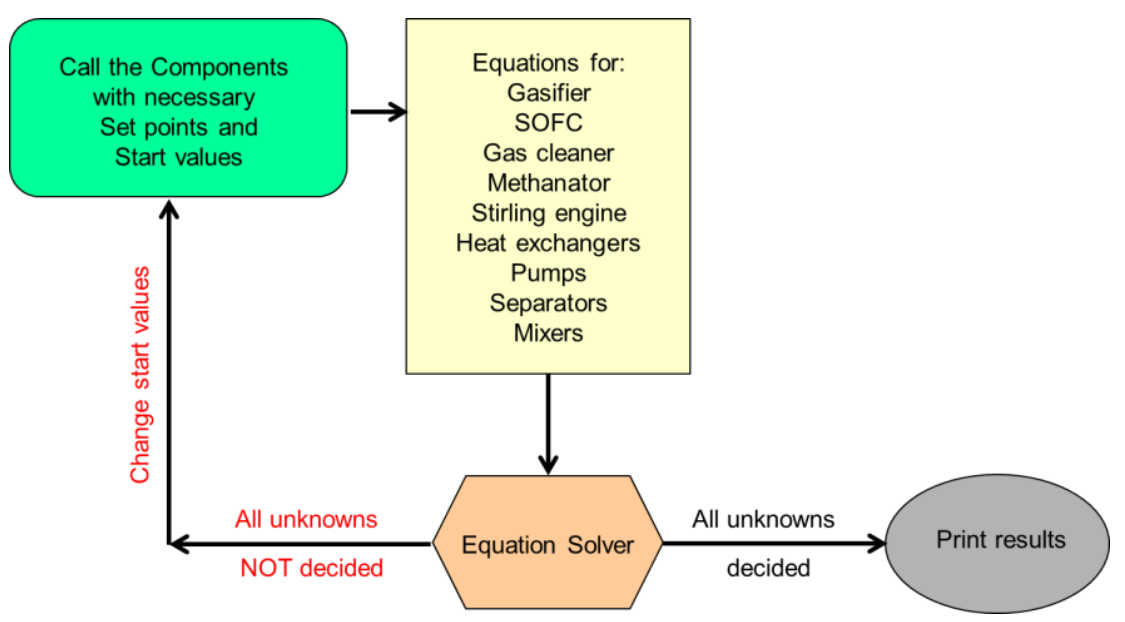

Figure 3. Calculation procedure.

\section{Plant Configurations}

The small-scale CHP system investigated in this study, consisting of an integrated MSW gasification plant with an SOFC system functioning as a topping cycle, and a Stirling engine with DHW heaters constituting the bottoming cycle, is shown in Fig. 4. An MSW gasification unit integrated with an SOFC-Stirling system with a high heat-power ratio in such a small-scale has not been investigated previously. MSW is fed into a gasifier for the production of syngas via a two-step process. The first step involves the pyrolysis of the feedstock, whereas the second step utilizes a fixed bed gasifier, where the pyrolyzed feedstock is gasified by steam and air, which act as gasification agents. A hot gas cleaner system (fuel conditioning system) is introduced, to remove the remaining contaminants present in the syngas.

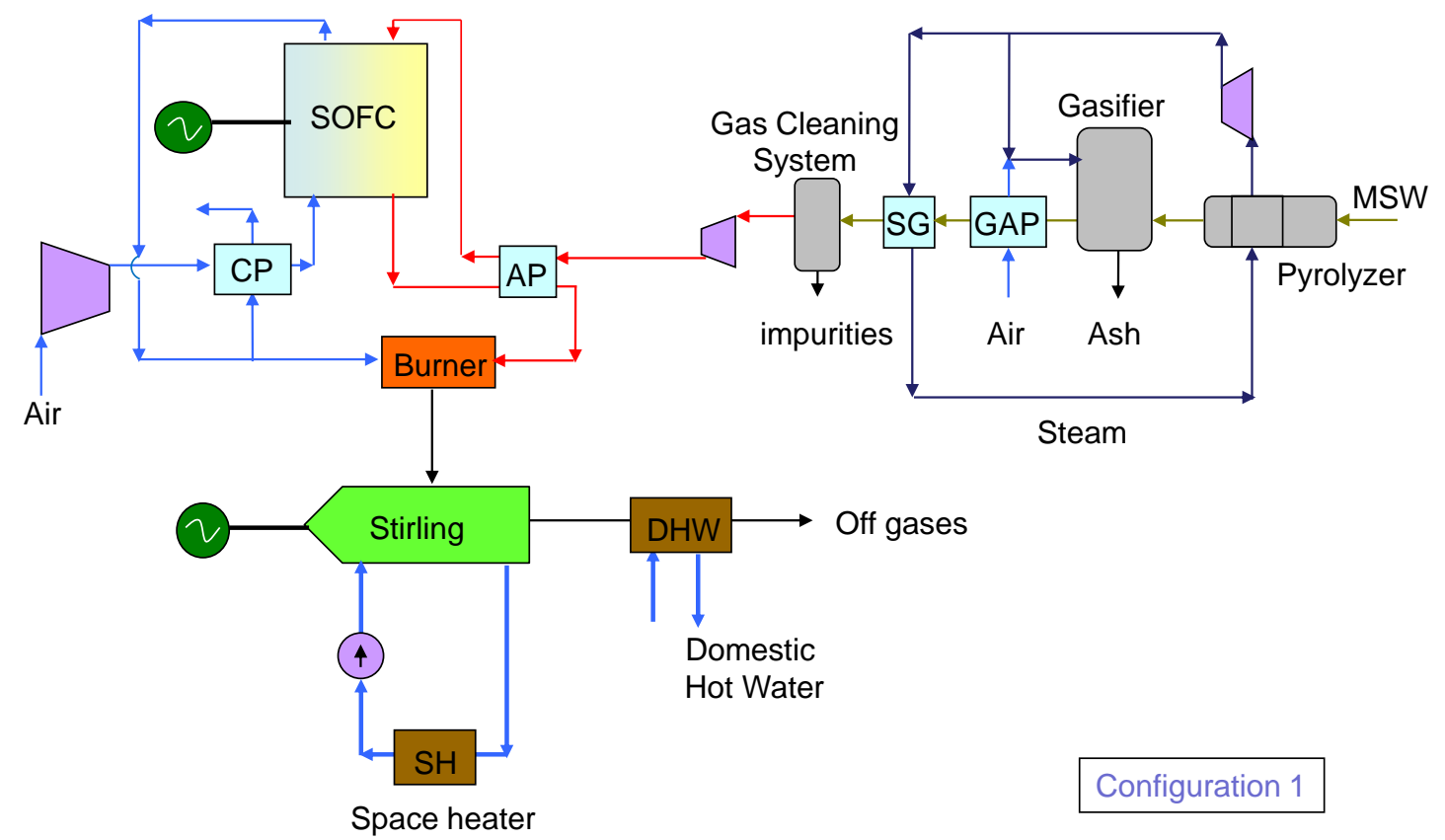

Figure 4. Basic plant configuration. $A P=$ Anode Preheater, $C P=$ Cathode Preheater, $D H W=$ Domestic Hot Water, GAP=Gasifier Air Preheater, SG=Steam Generator, SH=Space 
The syngas temperature is well over $400^{\circ} \mathrm{C}$ and the partial pressure of steam is above 2 , which enables simpler designing of the gas cleaning system. Owing to stringent environmental regulations in many industrial countries, the syngas cleaning systems are getting simpler than the exhaust cleaning system after combustion [3]. Since the plant size is rather small, silicon carbide filters and/or electromagnetic filters would likely be sufficient for syngas purification. However, if the plant size is increased, then the fuel conditioning system may also contain cyclones and/or scrubbers prior to silicon-based filters (or electromagnetic filters). It is also worth noting that practical engineering may be more complicated than thermodynamic analyses.

For the SOFC topping cycle, the ambient air at $15^{\circ} \mathrm{C}$ is compressed to the working pressure of the SOFC (normal pressure) and then heated in the cathode air preheater (CP) to $600^{\circ} \mathrm{C}$, before being introduced into the cathode side of the SOFC stack. The CP uses some of the SOFC off-air to heat the incoming air. The off-air is split into two streams, one entering the $\mathrm{CP}$ and the other entering the catalytic burner. On the anode side, the cleaned syngas is first pumped to compensate for the pressure drop along its way. It is then preheated to about $650^{\circ} \mathrm{C}$ using the offfuel out of the fuel cell, prior to being introduced on the anode side of the SOFC. The operating temperature of the fuel cell is assumed to be $780^{\circ} \mathrm{C}$, which is also used to preheat the incoming syngas. The burner is required because all of the fuel does not react in the fuel cell stacks, owing to incomplete fuel utilization. The entry temperatures mentioned above are the minimum entry temperatures and are an essential requirement for the proper functioning of SOFC stacks, not only to initiate the chemical reactions, but also to avoid cell thermal fractures.

Table 4. System operating input parameters

\begin{tabular}{l|c}
\hline MSW temperature $\left({ }^{\circ} \mathrm{C}\right)$ & 15 \\
Pyrolysis and drying temperature $\left({ }^{\circ} \mathrm{C}\right)$ & 150 \\
Gasifier temperature $\left({ }^{\circ} \mathrm{C}\right)$ & 800 \\
Gasifier pressure (bar) & 1 \\
Gasifier pressure drop (bar) & 0.005 \\
Gasifier carbon conversion factor & 1 \\
Gasifier non-equilibrium methane & 0.01 \\
Steam blower isentropic efficiency & 0.8 \\
Steam blower mechanical efficiency & 0.98 \\
Air temperature into gasifier $\left({ }^{\circ} \mathrm{C}\right)$ & 15 \\
Syngas blower isentropic efficiency & 0.7 \\
Syngas blower mechanical efficiency & 0.95 \\
Syngas cleaner pressure drop & 0.0049 \\
Cathode compressor air intake temperature $\left({ }^{\circ} \mathrm{C}\right)$ & 15 \\
Compressor isentropic efficiency & 0.7 \\
Compressor mechanical efficiency & 0.95 \\
Gas heat exchangers pressure drop & 0.01 \\
Pinch temperature for cathode preheater $\left({ }^{\circ} \mathrm{C}\right)$ & 20 \\
Burner inlet-outlet pressure ratio & 0.97 \\
Water pump efficiency & 0.95 \\
Inlet water temperature for hot water $\left({ }^{\circ} \mathrm{C}\right)$ & 20 \\
Outlet water temperature for hot water $\left({ }^{\circ} \mathrm{C}\right)$ & 60 \\
Off gas temperature after water heater $\left({ }^{\circ} \mathrm{C}\right)$ & 95 \\
\hline
\end{tabular}

For the bottoming cycle, a Stirling engine is implemented. The Stirling engine utilizes the combustion products leaving the burner as the heat source. Water, which is used as the heat sink, 
enters at $20^{\circ} \mathrm{C}$ and exits at $60^{\circ} \mathrm{C}$, making it appropriate for both $\mathrm{DHW}$ and space heating applications. In particular, the temperature of water is sufficient to address problems arising from bacteria such as Legionella. The heat remaining after the Stirling engine is used for DHW production. Water is constrained in the same manner as the heat sink, and the combustion products leave the system into the environment at approximately $95^{\circ} \mathrm{C}$, which is high enough to avoid corrosion issues. Other system operating parameters are mentioned in Table 4. Finally, it should be mentioned that practical systems require additional components such as valves, splitters, and control systems, which would slightly affect the plant thermodynamics. Such devices are not included in the plant configuration presented here.

In another configuration, a methanator is used after the fuel pump (Fig. 5). A methanator is a small catalytic device that increases the methane fraction in the syngas. Thus, the syngas is reformed exothermically in the methanator, wherein the mole fraction of methane in the gas is increased five-fold, from approximately 0.01 to nearly 0.05 . This increase in the methane content of the gas is a result of the reaction between $\mathrm{H}_{2}$ and $\mathrm{CO}$. Introducing the methanator will slightly decrease the electric power production from the SOFC stacks. However, since the reformation is highly exothermic, less heat will need to be extracted from the SOFC off-fuel to heat the fuel incoming to the fuel cell. This will eventually provide the Stirling engine with a larger amount of heat, because the fuel will be at a higher temperature when entering the burner and the combustion processes will therefore occur at a higher temperature. Secondly, the use of a gas containing a larger methane content in the SOFC causes endothermic internal reforming, which reduces the amount of air used for cooling purposes and for maintaining the SOFC operating temperature at $780^{\circ} \mathrm{C}$. Thus, the workload of the cathode compressor will eventually decrease.

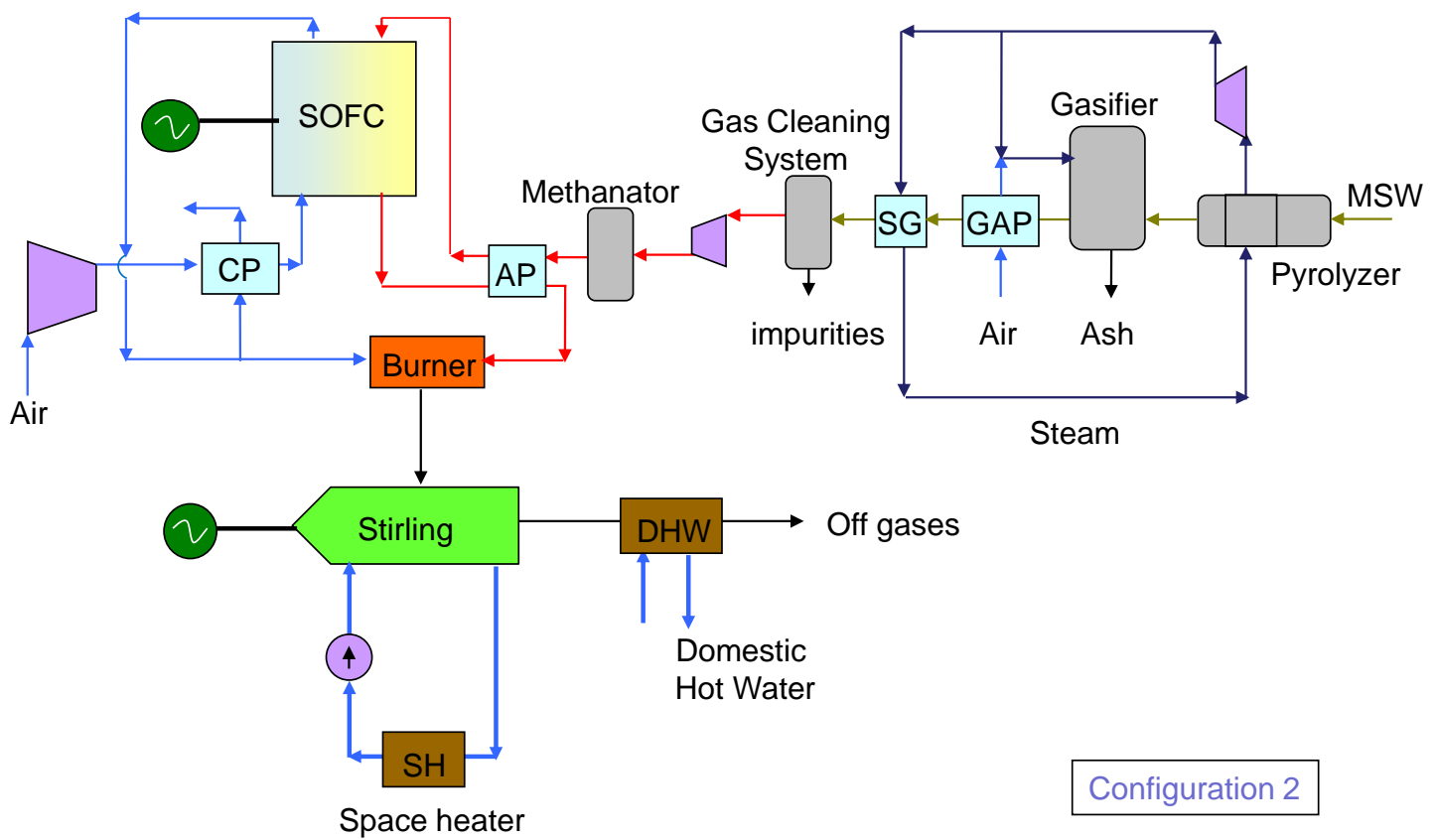

Figure 5. Improved plant design by introducing a methanator into the basic configuration.

It is worth mentioning that the temperature of the syngas is above $410^{\circ} \mathrm{C}$ with a steam partial pressure of over 2. As a result, carbon formation is negligible. On the other hand, the change in $\mathrm{CO}$ is very small from $0.35 \%$ to $0.31 \%$ (mole fraction), whereas the methane content is only increased from $0.013 \%$ to $0.046 \%$. Thus, the problem of carbon deposition is 
insignificant or less severe in a methanator. Therefore, this factor can be neglected. However, such problems must be accounted in reformers and pre-reformers.

As mentioned above, including a methanator after the fuel pump causes exothermic reformation of the syngas, which results in an increase in its temperature. The calculations show that the syngas temperature will be higher, after passing through the methanator, than the required temperature $\left(650^{\circ} \mathrm{C}\right)$, as a result of which the anode preheater can be eliminated. Fig. 6 shows the final configuration when the anode preheater is replaced by a methanator.

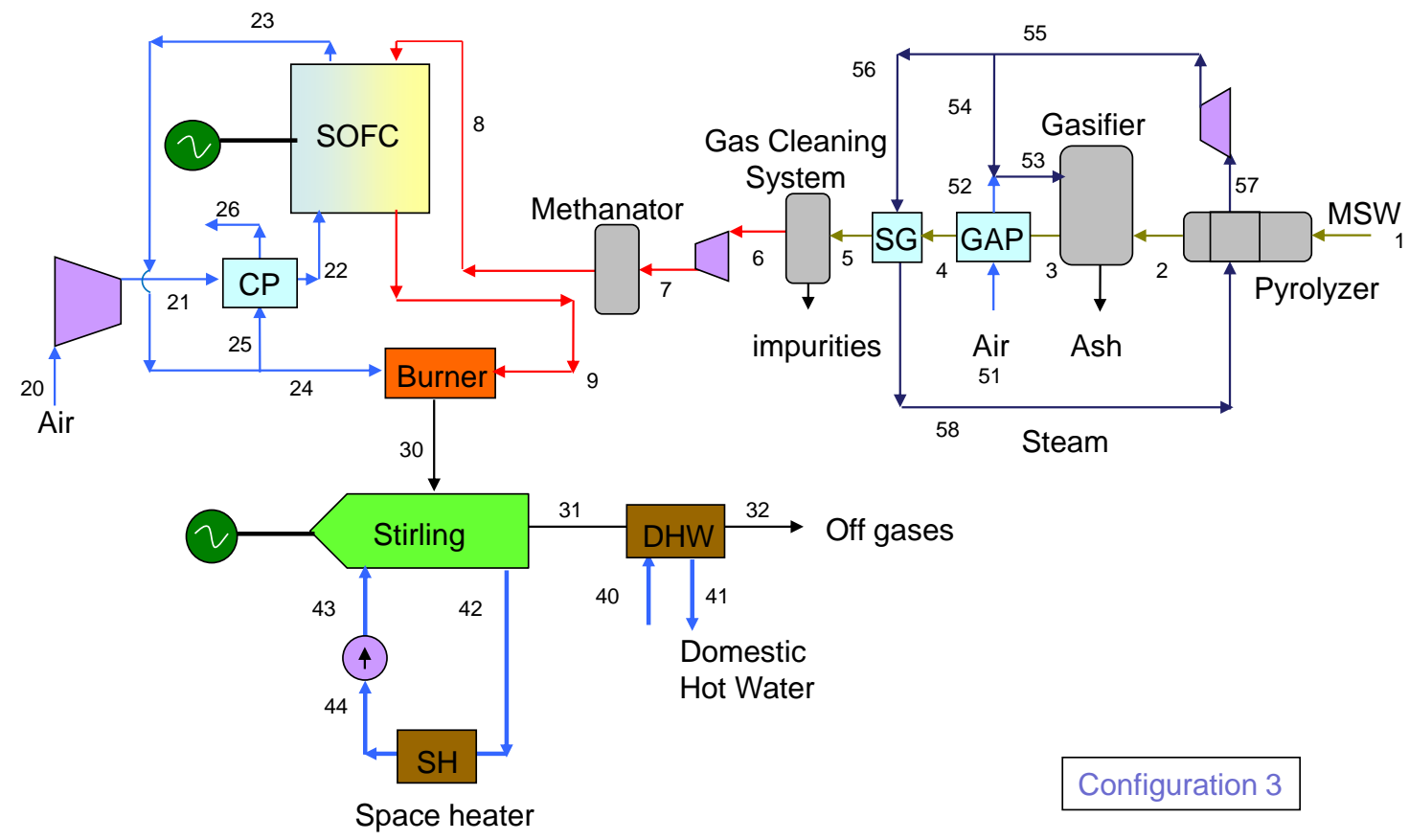

Figure 6. Final plant configuration with the methanator included and the anode preheater eliminated

Table 5 shows the thermodynamic data for configuration 3 in terms of mass flow, temperature, pressure, and gas composition. The table provides the pressure losses assumed for the different components. It also presents the fuel cross flow (from the cathode to the anode), detailed gas composition calculations, as well as accuracy in mass and energy conservation. The numbers in the first column correspond to the stream numbers specified in Fig. 6.

Table 5. Thermodynamic data for configuration 3 . The points in the first column of the table correspond to the ones mentioned in Fig. 6.

\begin{tabular}{|c|c|c|c|c|}
\hline $\begin{array}{l}\text { Point of consideration } \\
\text { (Selected Points) }\end{array}$ & $\begin{array}{l}\text { Mass Flow } \\
(\mathrm{kg} / \mathrm{s})\end{array}$ & $T\left({ }^{\circ} \mathrm{C}\right)$ & $p$ (bar) & $\begin{array}{l}\text { Composition } \\
\text { (molar base) }\end{array}$ \\
\hline $1: \mathrm{MSW}$ & 0.01 & 15 & 1.013 & $\begin{array}{c}\mathrm{H}_{2}: 0.0543, \mathrm{O}_{2}: 0.2977, \mathrm{~N}_{2}: 0.01086 \\
\mathrm{C}: 0.4308, \mathrm{~S}: 0.002715 \\
\mathrm{H}_{2} \mathrm{O}: 0.0950, \text { Ashes: } 0.1086\end{array}$ \\
\hline 3: Syngas after Gasifier & 0.03 & 800 & 0.998 & $\begin{array}{c}\mathrm{H}_{2}: 0.3056, \mathrm{~N}_{2}: 0.2859, \\
\mathrm{CO}: 0.3515, \mathrm{CO}_{2}: 0.02179, \\
\text { Steam: } 0.01750, \\
\text { Impurities: } 0.9129 \times 10^{-3}, \\
\mathrm{CH}_{4}: 0.01342, \text { Ar: } 0.3353 \times 10^{-2}\end{array}$ \\
\hline 4: Syngas before SG & - & 531.2 & 0.993 & - \\
\hline 5: Syngas after SG & - & 410.1 & 0.988 & - \\
\hline
\end{tabular}




\begin{tabular}{|c|c|c|c|c|}
\hline 7: Syngas before Methanator & - & 430.6 & 1.066 & $\begin{array}{c}\mathrm{H}_{2}: 0.3059, \mathrm{~N}_{2}: 0.2861, \mathrm{CO}: 0.3518, \\
\mathrm{CO}_{2}: 0.02181 \text {, Steam: 0.01752, } \\
\mathrm{CH}_{4}: 0.01344, \text { Ar: } 0.3356 \times 10^{-2}\end{array}$ \\
\hline 8: Methanated syngas & - & 673.0 & 1.066 & $\begin{array}{c}\mathrm{H}_{2}: 0.2565, \mathrm{~N}_{2}: 0.3047, \mathrm{CO}: 0.3141, \\
\mathrm{CO}_{2}: 0.05134, \text { Steam: } 0.02298, \\
\mathrm{CH}_{4}: 0.04674, \text { Ar: } 0.3574 \times 10^{-2}\end{array}$ \\
\hline 9: Fuel after SOFC & 0.04 & 780.0 & 1.056 & $\begin{array}{c}\mathrm{H}_{2}: 0.1092, \mathrm{~N}_{2}: 0.2796, \mathrm{CO}: 0.1085 \text {, } \\
\mathrm{CO}_{2}: 0.2697 \text {, Steam: } 0.2331, \\
\mathrm{CH}_{4}: 0.6517 \times 10^{-5} \text {, Ar: } 0.3574 \times 10^{-2}\end{array}$ \\
\hline 20: Air into Compressor & 0.28 & 15 & 1.013 & $\begin{array}{c}\mathrm{O}_{2}: 0.2075, \mathrm{~N}_{2}: 0.7729 \\
\mathrm{CO}_{2}: 0.3 \times 10^{-3}, \mathrm{H}_{2} \mathrm{O}: 0.01010 \\
\text { Ar: } 0.9200 \times 10^{-2}\end{array}$ \\
\hline 21: Cold air into CP & - & 27.1 & 1.121 & - \\
\hline 22: Air into SOFC & - & 600 & 1.111 & - \\
\hline 23: Air after SOFC & 0.27 & 780 & 1.056 & $\begin{array}{c}\mathrm{O}_{2}: 0.1802, \mathrm{~N}_{2}: 0.7995 \\
\mathrm{CO}_{2}: 0.3103 \times 10^{-3}, \text { Steam: } 0.01045, \\
\text { Ar: } 0.9517 \times 10^{-2}\end{array}$ \\
\hline 24: Air into burner & 0.06 & - & - & - \\
\hline 25: Hot air into $\mathrm{CP}$ & 0.22 & - & - & - \\
\hline 26: Hot air after $\mathrm{CP}$ & - & 48.3 & 1.046 & - \\
\hline 30: Flue gas after burner & 0.09 & 1412.3 & 1.024 & $\begin{array}{c}\mathrm{O}_{2}: 0.06295, \mathrm{~N}_{2}: 0.6111, \\
\mathrm{CO}_{2}: 0.1648, \text { Steam: } 0.1553, \\
\text { Ar: } 0.5826 \times 10^{-2}\end{array}$ \\
\hline 31: Flue & - & 640.6 & 1.014 & - \\
\hline 32: Flue gas depleted & - & 95 & 1.013 & - \\
\hline 40: Cold water before DHW & 0.27 & 6 & 1.200 & $\mathrm{H}_{2} \mathrm{O}: 1$ \\
\hline 41: DHW & - & 60 & 1.170 & - \\
\hline 42: SH & 0.23 & 60 & 1.300 & - \\
\hline 43: Cold water into engine & - & 6.01 & 1.330 & - \\
\hline 51: Air into GAP & 0.01 & 15 & 1.008 & $\begin{array}{c}\mathrm{O}_{2}: 0.2075, \mathrm{~N}_{2}: 0.7729, \\
\mathrm{CO}_{2}: 0.3 \times 10^{-3}, \mathrm{H}_{2} \mathrm{O}: 0.01010 \\
\text { Ar: } 0.9200 \times 10^{-2}\end{array}$ \\
\hline 52: Air after GAP & - & 794.0 & 1.003 & - \\
\hline 53: Air - Steam into Gasifier & 0.02 & 741.6 & 1.003 & $\begin{array}{c}\mathrm{O}_{2}: 0.1925, \mathrm{~N}_{2}: 0.7171, \\
\mathrm{CO}_{2}: 0.2784 \times 10^{-3}, \text { Steam: } 0.08153, \\
\text { Ar: } 0.8536 \times 10^{-2}\end{array}$ \\
\hline
\end{tabular}

\section{Results and Discussion}

The performances of the plant designs proposed above are summarized in Table 6 . In the table, configuration 1 refers to the basic configuration without the methanator, configuration 2 refers to the design that includes the methanator and the anode preheater, whereas configuration 3 is the final design that includes the methanator, but does not include the anode preheater. As shown in the table, the electrical efficiency of the final plant configuration is over $1 \%$ higher than the basic configuration. Electricity production by the SOFC is decreased, while power from the Stirling engine is increased and auxiliary power consumption is decreased, as a direct result of the inclusion of the methanator. Both space heating and hot water production will also decrease when a methanator is included. The presence of the anode preheater does not have a 
significant effect on the plant efficiency, power, and heat production. As shown in the table, the methanator provides two major benefits. Firstly, the amount of heat energy required to preheat the fuel will be reduced, resulting in a higher amount of heat available for the Stirling engine (through higher burner temperatures). Secondly, the compressor load decreases owing to the lower amount of cooling required for the fuel cell stacks to maintain the desired operating temperature. On the other hand, introducing the methanator decreases the amount of $\mathrm{H}_{2}$ in the fuel cell, which results in decreased cell voltage and power production.

Moreover, including the methanator and removing the anode preheater results in a decrease in the heat production (both space heating and DHW) by about $13 \mathrm{~kW}$, which in turn causes the CHP efficiency to decrease from about $95 \%$ to $92 \%$.

Table 6. Plant performance for different configurations.

\begin{tabular}{l|c|c|c}
\hline Configuration & Configuration & Configuration & Configuration \\
& 1 & 2 & 3 \\
\hline Electrical efficiency, (\%) & 45.03 & 45.98 & 46.07 \\
Plant electrical power, (kW) & 120 & 120 & 120 \\
SOFC power & 101.2 & 99.11 & 98.91 \\
Stirling power, $(\mathrm{kW})$ & 24.94 & 26.23 & 26.17 \\
Auxiliary power, $(\mathrm{kW})$ & 6.097 & 5.340 & 5.088 \\
Space heating, (kJ/s) & 67.08 & 60.37 & 60.09 \\
DHW, $(\mathrm{kJ} / \mathrm{s})$ & 66.96 & 60.26 & 60.26 \\
Total heat, $(\mathrm{kW})$ & 134.04 & 120.63 & 120.35 \\
CHP efficiency, $(\%)$ & 95.33 & 92.20 & 92.27 \\
MSW mass flow, $(\mathrm{kg} / \mathrm{h})$ & 54.02 & 52.91 & 52.81 \\
Methane content, $(\mathrm{mole} \%)$ & 0.0134 & 0.0456 & 0.0460 \\
Burner temperature, $\left({ }^{\circ} \mathrm{C}\right)$ & 1288.9 & 1405.8 & 1407.7 \\
\hline Configuration 1: basic plant without methanator & \multicolumn{3}{|l}{} \\
Configuration 2: basic plant with methanator and anode preheater \\
Configuration 3: basic plant with methanator and without anode preheater
\end{tabular}

\subsection{Effect of MSW composition}

The MSW composition can be changed depending on the waste type and the national recycling policy. In fact, the MSW composition could change daily and it may be interesting to investigate different MSW compositions feeding into the gasifier and study their effect on the plant performances. Therefore, various MSW compositions presented in the literature were studied and the results are shown in Table 7.

Table 7. Plant performance with different waste compositions: basic [22], waste 1 [33], wastes 2 to 5 [34], waste mean.

\begin{tabular}{c|c|c|c|c|c|c|c}
\hline Compound & Basic & Waste 1 & Waste 2 & Waste 3 & Waste 4 & Waste 5 & $\begin{array}{c}\text { Waste } \\
\text { Mean }\end{array}$ \\
\hline C & 0.476 & 0.40 & 0.459 & 0.483 & 0.408 & 0.422 & 0.491 \\
H & 0.06 & 0.069 & 0.068 & 0.076 & 0.067 & 0.061 & 0.063 \\
O & 0.329 & 0.354 & 0.337 & 0.316 & 0.389 & 0.399 & 0.323 \\
S & 0.003 & 0.001 & 0.0 & 0.001 & 0.006 & 0.001 & 0.002 \\
N & 0.012 & 0.006 & 0.011 & 0.006 & 0.009 & 0.008 & 0.007 \\
Ash & 0.12 & 0.17 & 0.123 & 0.116 & 0.114 & 0.104 & 0.114 \\
Cl & - & - & 0.002 & 0.002 & 0.007 & 0.005 & - \\
LHV, $(\mathrm{kW})$, & 19879 & 18900 & 18992 & 21314 & 15956 & 15639 & 19553 \\
\hline
\end{tabular}




\begin{tabular}{c|c|c|c|c|c|c|c}
\hline (dry basis) & & & & & & & \\
$c_{p},(\mathrm{~kJ} / \mathrm{kg})$ & 1.71 & 1.93 & 1.85 & 1.96 & 1.84 & 1.74 & 1.76 \\
Moisture & 0.095 & 0.04 & 0.04 & 0.045 & 0.155 & 0.04 & 0.073 \\
\hline
\end{tabular}

In the table, "waste mean" represents the mean of 19 different waste compositions derived from 12 different reports available in the literature [22, 33-43]. Thus, a huge amount of data was analyzed and the results are presented as mean composition values for MSW. The experimental values for the lower heating value (LHV) of the MSWs have been provided in some reports, whereas such values are missing in other reports. The LHV (dry basis) value of the missing MSW is then calculated as follows.

$$
\mathrm{LHV}=\mathrm{HHV}-(\mathrm{H} \times 2500)-(\text { Moisture } \times 2500)
$$

where HHV is the higher heating value. The moisture in MSW is provided in the corresponding references and $\mathrm{H}$ is the weight percentage of $\mathrm{H}_{2}$. $\mathrm{HHV}$ of the MSW is calculated from "Dulong" expression [22] as follows.

$$
\mathrm{HHV}=0.3383 \times \mathrm{C}+1.443 \times(\mathrm{H}-\mathrm{O} / 8)+0.0942 \times \mathrm{S} \quad \mathrm{MJ} / \mathrm{kg} .
$$

In this expression $\mathrm{C}, \mathrm{H}, \mathrm{O}$, and $\mathrm{S}$ are the weight percentages of $\mathrm{C}, \mathrm{H}, \mathrm{O}$, and $\mathrm{S}$, respectively. The heat capacity is calculated from the weighted average of the values of all the elementary components in the fuel (equation 28).

$$
c_{p, f u e l}=\frac{\sum_{i} x_{i} c_{p, i}}{\sum_{i} x_{i}}
$$

where $x_{i}$ is the mass fraction of each component and $c_{p, i}$ is the specific heat capacity of each elementary component. The values for the specific heat capacity of each component are adopted from a prior report [44], at 300K.

The calculation results are shown in Table 8. As shown in the table, the electrical efficiency of the plant changes from $\sim 43.6 \%$ to $\sim 48.1 \%$, depending on the MSW composition. The lowest plant efficiency is obtained with "waste 5", whereas the highest plant efficiency is achieved with "waste 1". The mean waste composition results in a plant efficiency of about $45.1 \%$. In general, the plant efficiency is high when the SOFC cell efficiency is high and its current density is low. This can also be visually seen in Fig. 7.

Table 8. Plant performance with different MSW compositions.

\begin{tabular}{c|c|c|c}
\hline Waste Type & $\begin{array}{c}\text { Electrical } \\
\text { efficiency }(\%)\end{array}$ & $\begin{array}{c}\text { SOFC } \\
\mathrm{E}_{\text {cell }}(\mathrm{V})\end{array}$ & $\begin{array}{c}\text { SOFC current } \\
\text { density }\left(\mathrm{A} / \mathrm{cm}^{2}\right)\end{array}$ \\
\hline Basic & 46.07 & 0.786 & 0.7382 \\
Waste 1 & 48.40 & 0.804 & 0.7247 \\
Waste 2 & 45.38 & 0.776 & 0.7469 \\
Waste 3 & 45.89 & 0.785 & 0.7399 \\
Waste 4 & 43.69 & 0.741 & 0.7751 \\
Waste 5 & 43.59 & 0.751 & 0.7663 \\
Waste mean & 45.13 & 0.772 & 0.7494 \\
\hline
\end{tabular}


As evident from the results obtained, the variation in the MSW composition does affect the power plant performance significantly. However, the MSW usually needs pre-treatment before being fed to the gasifier, which is not considered here. The final system performance may be affected overall by both the variation in composition as well as pre-treatment.

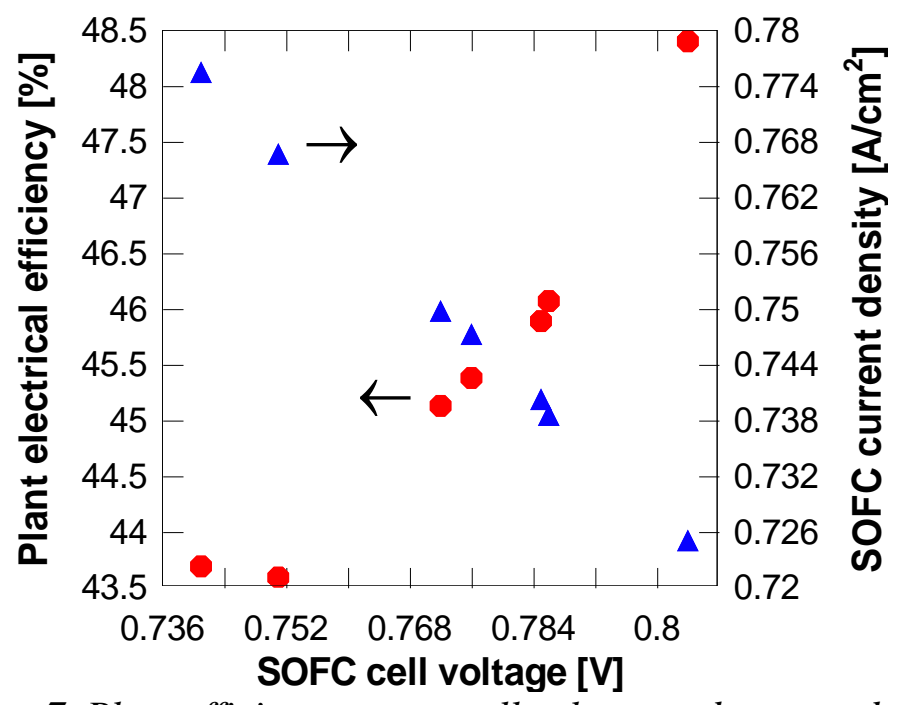

Figure 7. Plant efficiency versus cell voltage and current density with different compositions of municipal solid wastes.

\subsection{Effect of the Number of Stacks and Utilization Factor}

Both the number of SOFC stacks and the utilization factor have a significant effect on the electrical efficiency of the plant. As discussed by Rokni [45], increasing the number of stacks improves plant efficiency. The plant cost also directly depends on the number of stacks and therefore, the number of stacks should be chosen by taking into account the economy of the plant, in terms of either thermoeconomy or technoeconomy. Fig. 8 demonstrates this effect. For an SOFC utilization factor of 0.675 , the electrical efficiency increases from $\sim 45.1 \%$ to $\sim 47.5 \%$ for 100 and 4000 stacks, respectively. The cell voltage correspondingly increases from $0.766 \mathrm{~V}$ to $0.816 \mathrm{~V}$. Of course, it is uneconomical to design a plant with 4000 stacks when the power output is only $120 \mathrm{~kW}$ (Fig. 8a). As can be seen in Fig. 8a, the plant efficiency as well as the cell voltage does increase significantly, when the number of stacks is greater than 1000 .

Increasing the utilization factor to 0.8 also yields a similar trend (Fig. 8b). The plant efficiency sharply increases from $\sim 47.5 \%$ to $\sim 48 \%$, when the number of stacks is increased to about 3000. Further increase in the number of stacks does not have a significant influence on the plant efficiency. It is possible to reach an electrical efficiency of $\sim 48.2 \%$ for 80000 . stacks However, this would be uneconomical. Choosing about 150 or 160 stacks would be practically viable. Therefore, the number of stacks is set at 160 in the above calculations. 


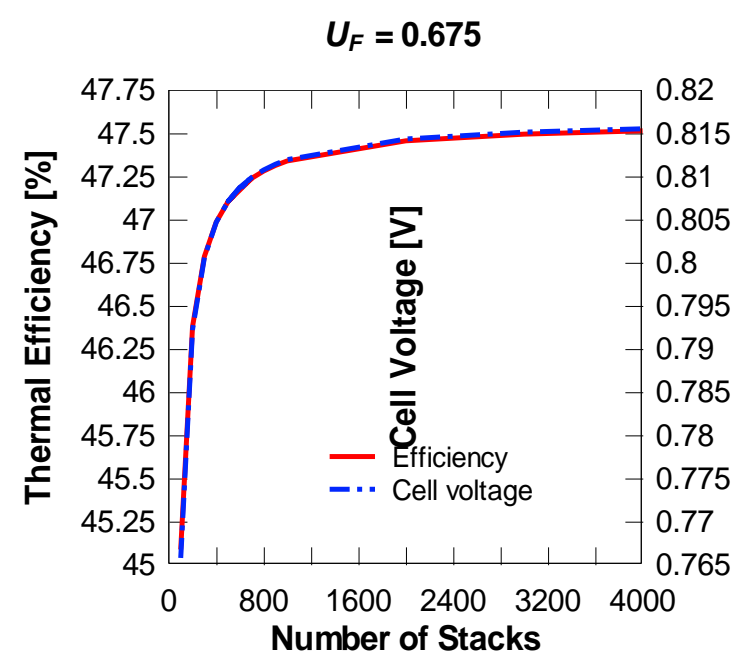

a)

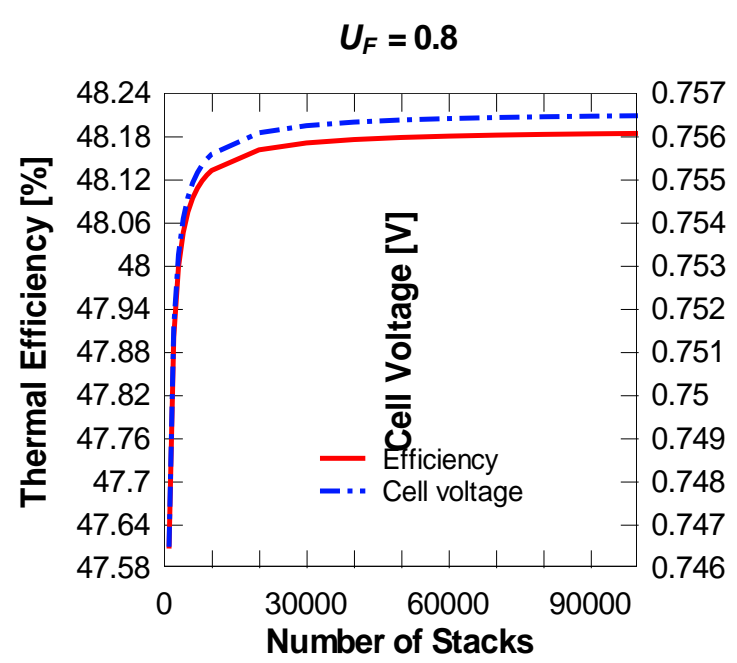

b)

Figure 8. Effect of number of stacks on the plant efficiency and cell voltage, for a utilization factor, $U_{F}$, of (a) 0.675 and (b) 0.8 .

\subsection{Effect of Gasifier and SOFC Operating Temperature}

The gasifier temperature cannot be controlled and may vary slightly during operation. Therefore, the gasifier temperature is assumed to vary between $750^{\circ} \mathrm{C}$ and $850^{\circ} \mathrm{C}$, oscillating around $800^{\circ} \mathrm{C}$ and the results are displayed in Fig. 9a. As seen in the figure, increasing the gasifier temperature decreases the plant efficiency and the net power slightly, owing to the change in the mole fraction of $\mathrm{H}_{2}$. By keeping the fuel mass flow constant and decreasing the gasifier operating temperature, the mole fraction of $\mathrm{H}_{2}$ decreases slightly, whereas the amounts of $\mathrm{CH}_{4}$ and $\mathrm{CO}$ remain essentially constant [46].

Another important parameter that is worth investigating is the operating temperature of the SOFCs. In the current study, the operating temperature of the cells is assumed to be $780^{\circ} \mathrm{C}$, although other values could be chosen. The operating temperature of the SOFCs varies from $750^{\circ} \mathrm{C}$ to $850^{\circ} \mathrm{C}$ depending on the electrode type and the manufacturer. Some manufacturers are developing cells with low operating temperatures (such as $650^{\circ} \mathrm{C}$ ), as part of their next generation product lines. Therefore, the operating temperature of the cells is allowed to vary from $650^{\circ} \mathrm{C}$ to $850^{\circ} \mathrm{C}$. As mentioned above, the inlet temperature of the cells is assumed to be lower than the average operating cell temperature. In this study, the difference between the SOFC operating temperature and the cathode inlet temperature is assumed to be $180^{\circ} \mathrm{C}$ on the cathode side. However, owing to the inclusion of the methanator, the inlet temperature on the anode side remains unchanged and is at a high value of about $674^{\circ} \mathrm{C}$. For planar SOFCs, a large difference between the inlet temperature and the average operating temperature may cause cell fatigue, which would permanently damage the cells. It is therefore reasonable to decrease the inlet temperature at the same rate as the average cell temperature, as done in this study. The outlet temperatures of the cells are assumed to have the same values as the average cell operating temperatures. The results are shown in Fig. 9b. The plant efficiency and the net power increases with a decrease in the SOFC operating temperature reaching a maximum, beyond which it decreases. The temperature corresponding to the maximum is found to be $690^{\circ} \mathrm{C}$. The trend can be explained by the fact that when the operating temperature of the SOFC decreases, the cooling demand for keeping the cell temperature at the desired value also decreases, as a result of which the compressor power consumption decreases and the net power and efficiency increase. At a certain point, the cell operating temperature will be too 
low compared to the methanator temperature and therefore, the stack cooling demand would increase resulting in lower plant power and efficiency.

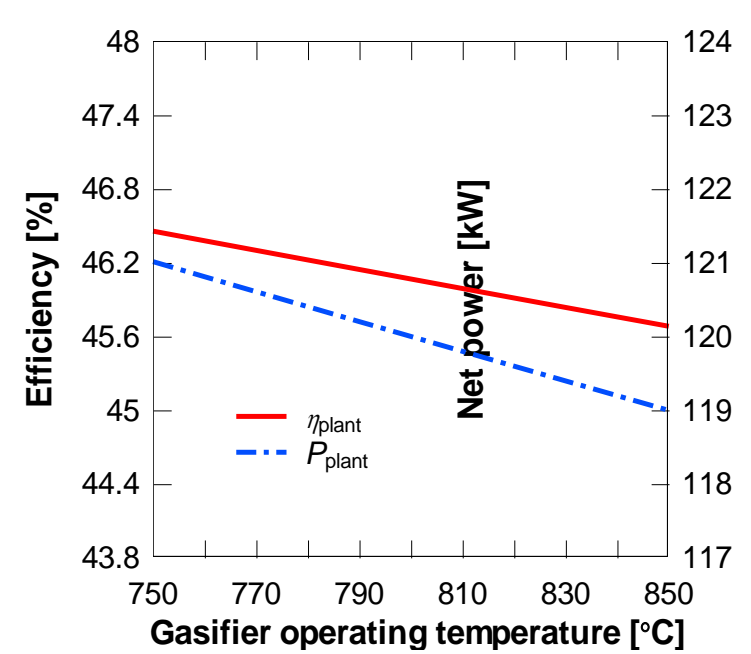

a)

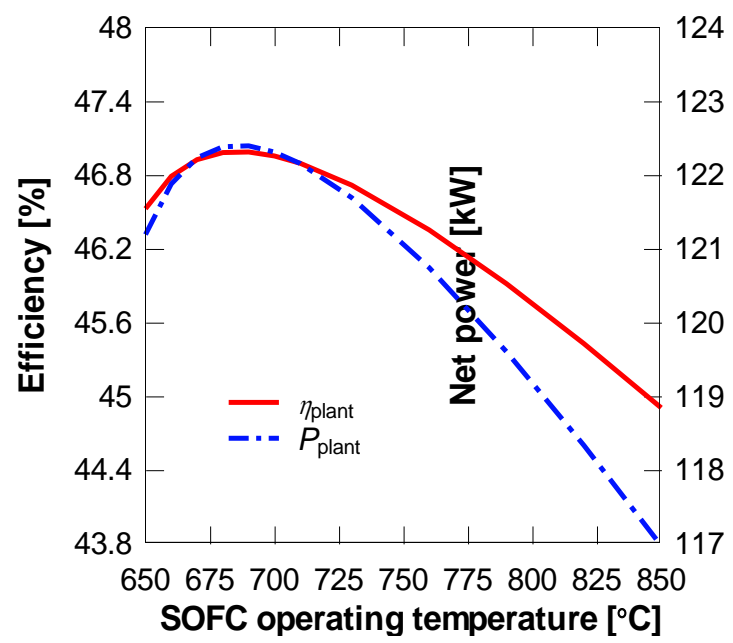

b)

Figure 9. (a) Effect of gasifier operating temperature and (b) SOFC operating temperature on plant efficiency and net power.

Another reason is that at a fixed $U_{F}$, increasing the cell voltage part of the chemical energy in the fuel results in additional electricity production and therefore, less heat will be released into the electrodes. Therefore, there would be less cooling demand (Fig. 10).

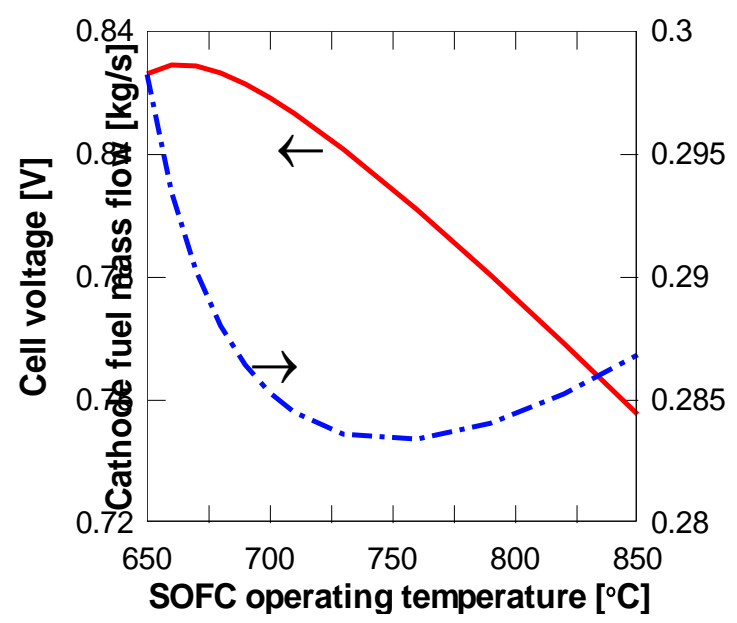

Figure 10. Effect of SOFC operating temperature on cell voltage.

\subsection{Effect of Stirling Cooling Temperature}

Other interesting parameters that are worth studying are the engine cooling temperature (engine cooler temperature difference) and the engine heater wall temperature. The engine cooling temperature may slightly change depending on the space heating demand, while the heater wall temperature depends mainly on the engine construction and the corresponding heat exchanger design.

The default engine cooling temperature is assumed to be $60^{\circ} \mathrm{C}$ in this study. The effect of temperature change on the engine power and plant efficiency is presented in Fig. 11a. Note that both the cooling temperature and the cooler temperature difference are changed simultaneously in the simulations. The cooling temperature is varied slightly from $55^{\circ} \mathrm{C}$ to $60^{\circ} \mathrm{C}$, to study its 
effect on the plant performance. As expected, decreasing the cooling temperature increases the engine power slightly and the plant efficiency marginally. The engine power decreases by about $1 \mathrm{~kW}$ for a $5^{\circ} \mathrm{C}$ increase in the cooling temperature.

The wall temperature for the engine's heater cannot be changed or controlled and depends entirely on the engine heat exchanger design. Depending on the manufacturer and the material choice, this temperature may be somewhat different from the desired (design or default) value. Thus, its effect on engine power and consequently, the plant efficiency may be interesting, as shown in Fig. 11b. As mentioned previously, the heater wall temperature is assumed to be $600^{\circ} \mathrm{C}$. Reducing this temperature decreases the engine power as well as the plant efficiency slightly. There also appears to be an optimum wall temperature at which the plant engine power is maximized. However, finding the optimum wall temperature is out of the scope of this study, because a large temperature deviation from the design point $\left(600^{\circ} \mathrm{C}\right)$ will change the engine characteristics completely and the other engine parameters, as a consequence.

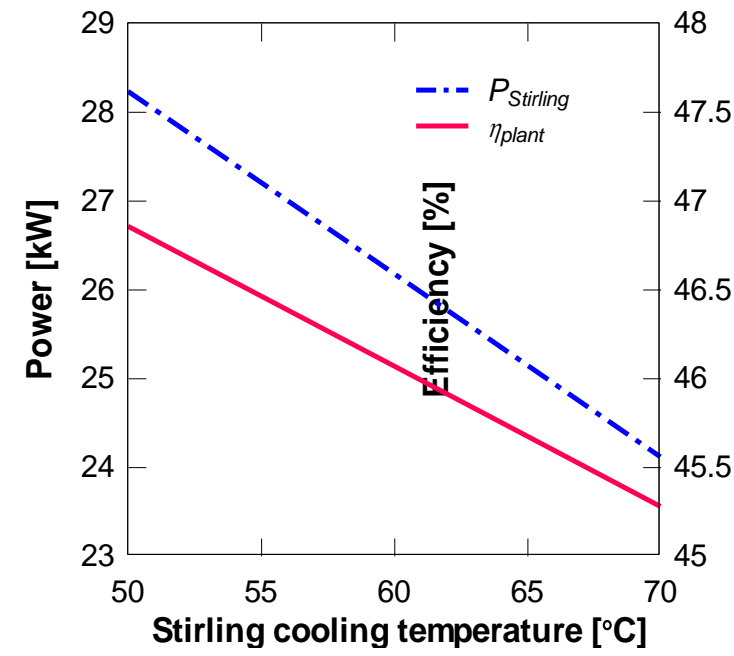

a)

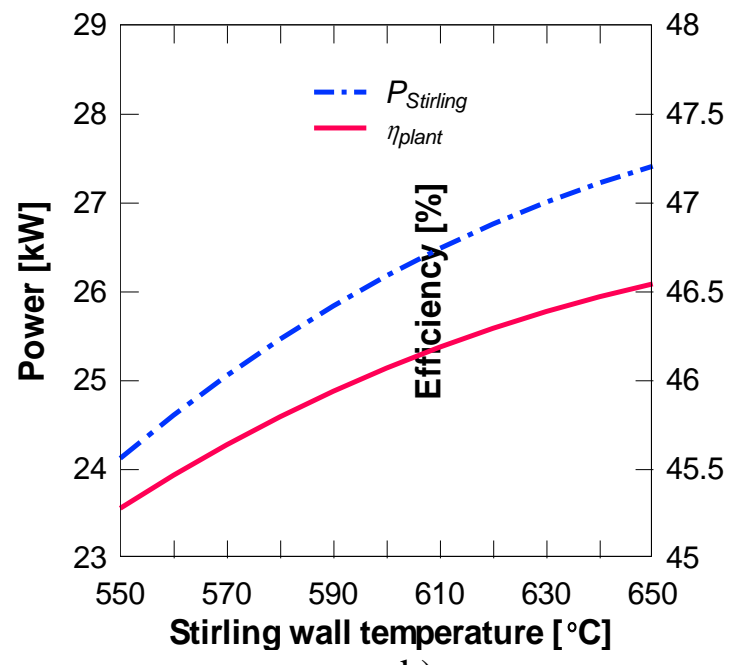

b)

Figure 11. Effect of Stirling engine cooling temperature difference (a) and wall surface temperature (b), on plant efficiency and engine power.

\section{Conclusions}

An integrated MSW gasification unit combined with an SOFC and a Stirling engine for application as a decentralized CHP plant with a $120 \mathrm{~kW}$ electric power capacity was thermodynamically analyzed. A plant electrical efficiency of up to $48 \%$ and a CPH efficiency of up to $95 \%$ can be achieved, depending on the plant design and the MSW composition. Introducing a methanator after syngas generation offers two main advantages. Firstly, the air compressor workload decreases owing to a lowered cooling requirement for SOFC stacks. Secondly, less heat is needed to preheat the incoming fuel to the SOFC, offering higher heat availability for the bottoming cycle, resulting in an increase in its electric power production. Despite a lower fuel cell voltage, the plant electrical efficiency increases by using a methanator. Different MSW compositions provide different plant efficiencies, ranging from $43 \%$ to $48 \%$. Seven different MSW compositions were used in the simulations and 19 different MSW compositions were screened to determine a mean composition and study its effect on the plant performance. A $45 \%$ electrical efficiency was achieved for the mean composition. Further, increasing the gasifier temperature decreased the plant efficiency, owing to a change in the mole fractions of the gas components in the gasifier. However, the maximum plant efficiency was 
achieved when the SOFC operating temperature was $690^{\circ} \mathrm{C}$, if the fuel mass flow was unchanged.

\section{References}

[1] Sanchez D, Chacartegui R, Torres M, Sanchez T. Stirling based fuel cell hybrid systems: an alternative for molten carbonate fuel cells. Power Sources 2008;192:84-93.

[2] Rokni M. Thermodynamic analysis of SOFC (solid oxide fuel cell) - Stirling hybrid plants using alternative fuels. J Energy 2013;61:87-97.

[3] Morris M, Waldheim L. Energy recovery from solid waste fuels using advanced gasification technology. Waste Management 1998;18(6-8):557-564.

[4] Calise F, Dentice d'Accadia M, Palombo A, Vanoli L. Simulation and exergy analysis of a hybrid solid oxide fuel cell (SOFC)-Gas turbine system. J Energy 2006;31:327899.

[5] Doherty W, Reynolds A, Kennedy D. Computer simulation of a biomass gasificationsolid oxide fuel cell power system using Aspen Plus. J Energy 2010;35(12):4545-55.

[6] Ghosh S, De S. Energy Analysis of a cogeneration plant using coal gasification and solid oxide fuel cell. J Energy 2006;31(2-3),345-363.

[7] Buchinger G, Hinterreiter P, Raab T, Griesser S, Lawlor V, Klein K, Kuehn S, Sitte W, Meissner D. Stability of micro tubular SOFCs operated with synthetic wood gases and wood gas components. IEEE 2007;1-4244-0632-3/07:444-449.

[8] EG\&G and G Technical Services Inc. 2004. Fuel Cell Handbook, 7th edition, U.S. Departement of Energy, Office of Fossil Energy, National Energy Technology Laboratory.

[9] Riensche E, Achenbach E, Froning D, Haines MR, Heidug WK, Lokurlu A, Adrian S. Clean combined-cycle SOFC power plant-cell modeling and process analysis. J Power Sources 2000;86(1-2):404-410.

[10] Haseli Y, Dincer I, Natere GF. Thermodynamic modeling of a gas turbine cycle combined with a solid oxide fuel cell. Int J Hydrogen Energy 2008;33(20):5811-22.

[11] Rokni M. Thermodynamic analysis of an integrated solid oxide fuel cell cycle with a Rankine cycle. Energy Conversion and Management 2010;51(12):2724-32.

[12] Rokni M. Plant characteristics of an integrated solid oxide fuel cell and a steam cycle. J Energy 2010;35:4691-99.

[13] Proell T, Aichering C, Rauch R, Hofbauer H. Coupling of biomass steam gasification and SOFC-gas turbine hybrid system for highly efficient electricity generation. ASME turbo Expo Proceeding 2004;GT2004-53900:103-112.

[14] Bang-Møller C, Rokni M. Thermodynamic performance study on biomass gasification, solid oxide fuel cell and micro gas turbine hybrid systems. Energy Conversion and Management 2010;51(12):2330-39.

[15] Rokni M. Thermodynamic investigation of an integrated gasification plant with solid oxide fuel cell and steam cycles. J Green 2012;2:71-86.

[16] Liese E. Comparison of Preanode and Postanode Carbon Dioxide Separation for IGFC Systems. ASME Gas Turbines and Power;132(061703):1-8.

[17] Spallina V, Romano MC, Campanari S, Lozza G. A SOFC-Based Integrated Gasification Fuel Cell Cycle With $\mathrm{CO}_{2}$ Capture. ASME Gas Turbines and Power;133(071706):1-10. 
[18] Henriksen U, Ahrenfeldt J, Jensen TK, Gøbel B, Bentzen JD, Hindsgaul C, Sørensen $\mathrm{LH}$. The design, construction and operation of a $75 \mathrm{~kW}$ two-stage gasifier. J Energy 2006;31(10-11):1542-53.

[19] Ahrenfeldt J, Henriksen U, Jensen TK, Gøbel B, Wiese L, Kather A, Egsgaard H. Validation of a continuous combined heat and power (CHP) operation of a two-stage biomass gasifier. Energy \& Fuels 2006;20(6):2672-80.

[20] Hofmann PH, Schweiger A, Fryda L, Panopoulos K, Hohenwarter U, Bentzen J, Ouweltjes JP, Ahrenfeldt J, Henriksen U, Kakaras E. High temperature electrolyte supported Ni-GDC/YSZ/LSM SOFC operation on two stage Viking gasifier product gas. J Power Sources 2007;173(1):357-366.

[21] Smith JM, Van Ness HC, Abbott MM. 2005. Introduction to Chemical Engineering Thermodynamics, 7th edition, Boston:McGraw-Hill.

[22] Channiwala SA, Parikh PP. A unified correlation for estimating HHV of solid, liquid and gaseous fuels. Fuel 2002;81(8);1051-63.

[23] Holtappels P, DeHaart LGJ, Stimming U, Vinke IC, Mogensen M. Reaction of CO/CO2 gas mixtures on Ni-YSZ cermet electrode. J Applied Electrochemistry 1999;29:561-68.

[24] Matsuzaki Y Yasuda I. Electrochemical oxidation of $\mathrm{H} 2$ and $\mathrm{CO}$ in a $\mathrm{H} 2-\mathrm{H} 2 \mathrm{O}-\mathrm{CO}-\mathrm{CO} 2$ system at the interface of a Ni-YSZ cermet electrode and YSZ electrolyte. J Electrochemical Society 2000;147(5):1630-35.

[25] Keegan KM, Khaleel M, Chick LA, Recknagle K, Simner SP, Diebler J. Analysis of a planar solid oxide fuel cell based automotive auxiliary power unit, SAE Technical Paper Series 2002;No. 2002-01-0413.

[26] Zhu H, Kee RJ. A general mathematical model for analyzing the performance of fuelcell membrane-electrode assemblies. J Power Sources 2003;117:61-74.

[27] Costamagna P, Selimovic A, Del Borghi M, Agnew G. Electrochemical model of the integrated planar solid oxide fuel cell (IP-SOFC). Chemical Engineering Journal 2004;102(1):61-69.

[28] Christiansen N, Hansen JB, Holm-Larsen H, Linderoth S, Larsen PH, Hendriksen PV, Hagen A. Solid oxide fuel cell development at Topsoe fuel cell and Risø. J Electrochemical Society 2007;7(1):31-38.

[29] Winnick J. 1997. Chemical engineering thermodynamics. John Wiley \&Sons, New Yourk.

[30] Reader GT. The pseudo Stirling cycle - a suitable performance criterion. Proceeding of the 13th intersociety energy conversion engineering conference 1979; 3:1763-770, San Diego, California, August 20-25.

[31] Elmegaard B, Houbak N. DNA - a general energy system simulation tool, proceeding of SIMS, Trondheim, Norway; 2005.

[32] Perstrup C. Analysis of power plant installation based on network theory (in Danish). M.Sc. thesis, Technical University of Denmark, Laboratory of Energetics, Denmark; 1989.

[33] Buah WK, Cunliffe AM, Williams PT. Characterization of products from the pyrolysis of municipal solid waste. Process Safety and Environmental Protection 2007;85(B5);450-57.

[34] Cozzani V, Petarca L, Tognotti L. Devolatilization and pyrolysis of refuse derived fuels: characterization and kinetic modelling by a thermogravimetric and calorimetric approach. Fuel 1995;74(6);903-12.

[35] Guan Y, Luo S, Liu S, Xiao B, Cai L. Steam catalytic gasification of municipal solid waste for producing tar-free fuel gas. Int J Hydrogen Energy 2009;34(23):9341-46.

[36] Bebar L, Stehlık P, Havlen L, Oral J. Analysis of using gasification and incineration for thermal processing of wastes. Applied Thermal Engineering 2005;25(7);1045-55. 
[37] Dalai K, Batta N, Eswaramoorthi I, Schoenau GJ. Gasification of refuse derived fuel in a fixed bed reactor for syngas production. Waste Management 2009;29(1);252-8.

[38] Galvagno S, Casciaro G, Casu S, Martino M, Mingazzini C, Russo A, Portofino S. Steam gasification of tyre waste, poplar, and refuse-derived fuel: A comparative analysis. Waste Management 2009;29(2);678-89.

[39] Gordillo G, Annamalai K. Adiabatic fixed bed gasification of dairy biomass with air and steam. Fuel 2010;(89(2);384-91.

[40] Baggio P, Baratieri M, Fiori L, Grigiante M, Avi D, Tosi P. Experimental and modeling analysis of a batch gasification/pyrolysis reactor. Energy Conversion and Management 2009;50(6);1426-35.

[41] Hernandez-Atonal FD, Ryu C, Sharifi VN, Swithenbank J. Combustion of refusederived fuel in a fluidised bed. Chemical Engineering Science 2007;62(1-2);627-35.

[42] Piao G, Aono S, Mori S, Deguchi S, Fujima Y, Kondoh M, Yamaguchi M. Combustion of refuse derived fuel in a fluidized bed. Waste Management 1998;18(6-8);509-12.

[43] Piao G, Aono S, Kondoh M, Yamazaki R, Mori S. Combustion test of refuse derived fuel in a fluidized bed. Waste Management 2000;20(5-6); 443-7.

[44] Incropera F.P., DeWitt D.P., Bergman TL and Lavine A.S. 2006. Introduction to Heat Transfer. 5th ed, Wiley, ISBN 978-0471457275.

[45] Rokni M. Thermodynamic and thermoeconomic analysis of a system with biomass gasification, solid oxide fuel cell (SOFC) and Stirling engine. Energy 2014;76:19-31.

[46] Rokni M. Biomass gasification integrated with a solid oxide fuel cell and Stirling engine, Energy 2014;77:6-18.

\section{Nomenclature}

$c_{p} \quad$ specific heat, $\mathrm{J} / \mathrm{kg}^{\circ} \mathrm{C}$

E Voltage, V

$F \quad$ Faradays constant, $\mathrm{C} / \mathrm{mol}$

$g^{0} \quad$ Standard Gibbs free energy, $\mathrm{J} / \mathrm{mol}$

$g_{f} \quad$ Gibbs free energy, $\mathrm{J} / \mathrm{mol}$

$\dot{m} \quad$ Mass flow, kg/s

$\dot{n} \quad$ Molar reaction rate, $\mathrm{mol} / \mathrm{s}$

$n_{e} \quad$ number of electron

$P \quad$ Power, W

$p \quad$ Pressure, bar

$T \quad$ Operating temperature, $\mathrm{K}$

$R \quad$ Universal gas constant, $\mathrm{J} / \mathrm{mol} \mathrm{K}$

$U_{F} \quad$ Fuel utilization factor

$x \quad$ mass fraction

\section{Greek Letters}

$\Delta \quad$ difference

$\eta \quad$ efficiency

\section{Subscripts}

act activation

conc concentration

ohm ohmic 
rev reversible

$v \quad$ voltage

\section{Abbreviations}

AP Anode pre-heater

CHP Combined heat and power

$\mathrm{CP}$ Cathode air pre-heater

GAP Gasifier air pre-heater

HHV Higher heating value

LHV Lower heating value

MSW Municipal solid waste

SG Steam generator

SOFC Solid oxide fuel cell

SH Space heater

DHW Domestic hot water 